DESA Working Paper No. 99

ST/ESA/2010/DWP/99

October 2010

\title{
Labour Markets Trends, Financial Globalization and the current crisis in Developing Countries
}

\author{
Rolph van der Hoeven
}

\begin{abstract}
The current wave of globalization has profound labour market effects, accentuated, in many cases, by the current financial and economic crisis. This paper reviews general labour market trends and country examples, arguing that the current globalization process makes labour's position more precarious, a trend magnified by the current crisis. This is consistent with the policy reactions to the crisis: governments have (rightly) acted as a banker of last resort to avoid the collapse of the financial system, but, despite stimulus plans and monetary easing and some labour market policies, have not really acted as an employer of last resort.

JEL Classification: E24 (Employment, Wages and Unemployment), E64 (Incomes Policy), F42 (International Policy Coordination and Finance), J21 (Labour Force and Employment)

Keywords: Globalization, Financial Globalization, Employment, Income inequality, Financial Crisis
\end{abstract}

Rolph van der Hoeven is Professor of Employment and Development Economics at the Institute of Social Studies, The Hague.

Comments should be addressed by e-mail to the author: hoeven@iss.nl 


\section{Contents}

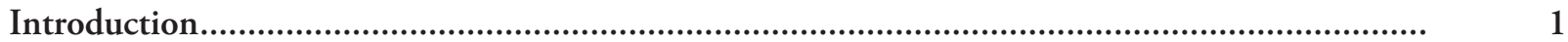

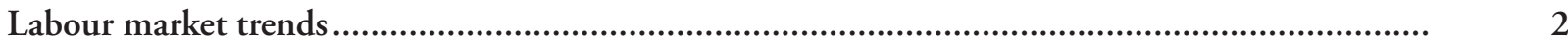

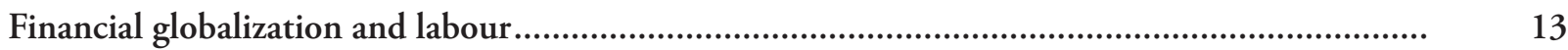

The effect of the current crisis on labour and possible policy responses.......................................... 24

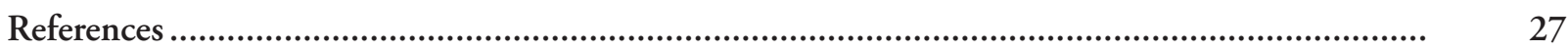

Figures:

1. Employment-to-population ratio, 1991-2008, various regions in the world ....................... 3

2. Male employment-to-population ratio, 1991-2008, various regions in the world ............... 4

3. Percentage of employment in services, 1991-2008, various regions in the world................ 4

4. Percentage of employment in industry, 1991-2008, various regions in the world............... $\quad 5$

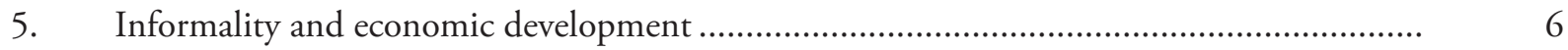

6. Informal employment and GDP in Latin America and South-East Asia ............................ 7

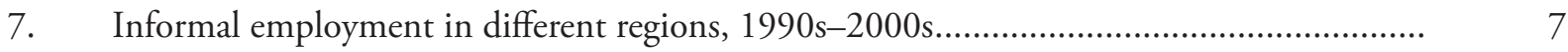

8. Changes in wage share in various countries, 1995-2007 ...................................................

9. Changes in wage inequality between top and bottom

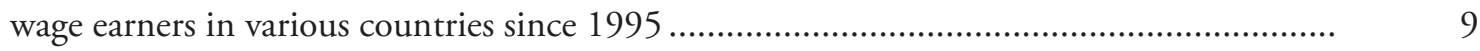

10. Annual growth of employment, value added and exports

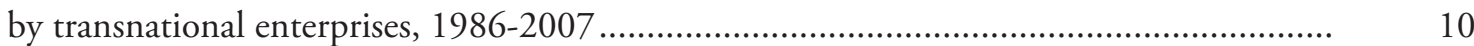

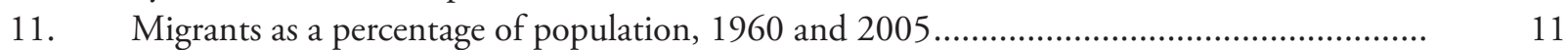

12. Workers' remittances and compensation of employees

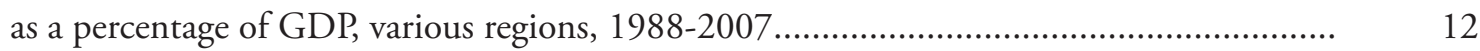

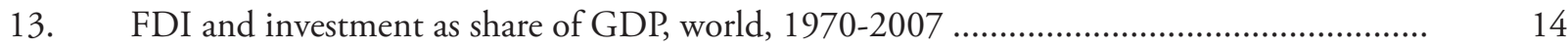

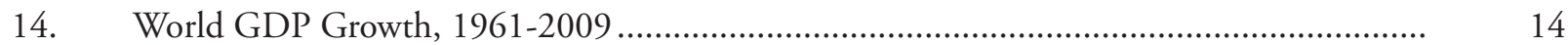

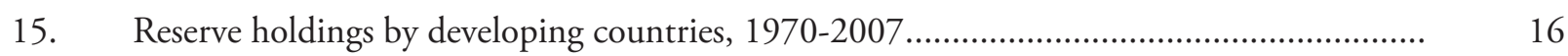

16. Typical growth path after a financial crisis in rich and poor countries............................... 17

17. Medium-term effects of financial crises on unemployment in several Latin American Countries ..................................................................................... 19

18. Medium-term effects of the financial crises on unemployment in Turkey .......................... 21

19. Medium-term effects of the East Asian financial crises on unemployment ......................... 22

20. A comparison of downturns in developing countries during several recent recessions ......... 25

UN/DESA Working Papers are preliminary documents circulated in a limited number of copies and posted on the DESA website at http://www.un.org/en/development/desa/ papers/2010 to stimulate discussion and critical comment. The views and opinions expressed herein are those of the author and do not necessarily reflect those of the United Nations Secretariat. The designations and terminology employed may not conform to United Nations practice and do not imply the expression of any opinion whatsoever on the part of the Organization.

Editor: Nazrul S. Islam
United Nations

Department of Economic and Social Affairs

2 United Nations Plaza, Room DC2-1428

New York, N.Y. 10017, USA

Tel: (1-212) 963-4761 • Fax: (1-212) 963-4444

e-mail: esa@un.org

http://www.un.org/en/development/desa/papers/2010 


\title{
Labour Markets Trends, Financial Globalization and the current crisis in Developing Countries
}

\author{
Rolph van der Hoeven ${ }^{1}$
}

\section{Introduction}

The current wave of globalization, starting around 1999-2000 (with the fall of the Berlin Wall, changes in the concepts of development and ensuing capital market liberalization following trade liberalization undertaken earlier), had profound effects on the labour market and the employment situation of workers all over the world. These effects, in many cases, have been accentuated by the current financial and economic crisis. The purpose of this paper is first to review some general labour market trends in this period of globalization and second to highlight labour market trends associated with financial globalization

A major question is, of course, whether ongoing analyses of employment, inequality, and globalization remain relevant in the current context of the large financial and economic crisis. This paper argues that they do, at least for the following two reasons:

First, several elements of the ongoing process of globalization, especially the unfettered markets, (including the labour market) ${ }^{2}$ and the growing inequality (resulting for many households indebting themselves in order to keep up spending on basic needs), ${ }^{3}$ have given rise to the current crisis. Therefore, the analysis of the structure and nature of current globalization and its impact on employment and inequality, as well as policy recommendations to alter current globalization processes, are even more relevant in times of the current crisis.

Second, there is growing evidence that the employment, human and social effects of the financial and economic crisis will last for a while, especially if no corrective action is taken. Reinhardt and Rogoff (2009), for example, foresee that the decline in gross domestic product (GDP) growth will lead to rising unemployment with a much longer duration than the decline in GDP growth itself. Based on a sample of past crises, both in the North and in the South, they observe an average slump in employment lasting 4.8 years, compared to a decline in output growth of only 1.9 years. ${ }^{4}$ There is also evidence that indicators for human development exhibit a similar ratchet effect. Arbache and Page (2007), for example, shows that child

1 I would like to thank Malte Luebker for valuable inputs, especially for sections 3.2-3, and Theo Sparreboom for providing data from ILO KILM data set.

2 Part of growing inequality can be explained by the policies undertaken during the process of liberalization and adjustment, including policies to make the labour market more efficient. See Van der Hoeven and Taylor (2000).

3 "(O)ver the past 30 years, particularly, there has been an increase in inequality. In effect, we have been transferring money from the poor to the rich, from people who would spend the money to people who do not need to spend the money, and the result of that is weaker aggregate demand. The United States thought it could solve the problem: Americans who had no money were told to keep spending as if they had it. They enjoyed it for a while. A massive debt finance bubble enabled them to continue to spend." (Stiglitz, 2009, pp. 7-8).

4 Van der Hoeven and Luebker (2007) investigates the behaviour of labour shares in national incomes during recent periods of financial crises and observes a ratchet effect: labour shares decline during crises but in many cases do not return, once the economy has picked up, to their pre-crisis level. 
mortality in Africa increases during growth decelerations, but hardly falls during accelerations. Furthermore, primary school completion rates and life expectancy remain substantially lower in countries experiencing growth decelerations.

There are thus strong reasons to include policies for employment, income inequality and human development as priority issues in designing both short- and long-term policies to deal with the crisis. But, might there be tradeoffs between these policies for employment, income inequality and human development? A recent study (Angeles-Castro, 2006) on explanations for growing inequality over the last decade concludes that high employment levels reduce inequality and, especially for developing nations, high employment levels in the industrial sector reduce inequality. Employment expansion and reduction of income inequality can thus be combined objectives in policymaking. In a similar vein, Stewart and Ranis (2002) argues that human development and economic growth can be joint and mutually reinforcing targets for policymaking. It thus seems more than appropriate to argue for greater attention to employment, income inequality and human development in times of crises.

Stiglitz (2009) argues that the dominant view during the current process of globalization was that unfettered markets were sufficient to ensure economic efficiency. The best role for Government was a limited one, and somehow the benefits of growth resulting from unfettered markets would trickle down to everyone in society. Added to that was the view of a dominant strand of economists that the problem in the market economy was rigid wages, and that if it were not for wage rigidities, the economy would work in the way that classical economics predicted. According to Stiglitz, the implication of the Keynesian rigid-wage theory was very invidious but pervasive: Get rid of the rigid wages, and let labour markets be more "flexible". That has been the basis of a whole set of doctrines undermining job protections and labour rights. But as he rightly observes, wages are not rigid: in the Great Depression wages fell by about one third. The problem that Keynes had recognized was that wages can be too flexible. Stiglitz observes that lack of aggregate demand was the problem with the Great Depression, just as lack of aggregate demand is the problem today. Accordingly, imposing more wage flexibility can result in exacerbating the underlying problem of lack of aggregate demand. He puts the nature of the problem that we face today as follows: "The people in the global economy have the same skills as before the crisis, and the machines and real resources are the same as before the crisis. The problem is that there is an organizational failure, a coordination failure, and a macroeconomic failure."

\section{Labour market trends}

Before discussing the consequences of financial globalization on employment in more detail, we will present a longer term picture of the development of the labour markets in developing regions. We can distinguish a number of general labour market trends over the last two decades.

\section{Decline in the employment-to-population rate}

First is the decline in the employment-to-population rate for most regions in the world. For the world as a whole, the employment-to-population ratio seems to have remained rather constant, but there are important regional differences (see figure 1). All three Asian regions and sub-Saharan Africa had the highest employment-to-population ratio at the beginning of the 1990s, but thereafter experienced declines by several percentage points.

In contrast, the ratio increased slightly from much lower levels in the Middle East, North Africa and Latin America. The lower employment-to-population level in these regions can be explained by very 
Figure 1: Employment-to-population ratio, 1991-2008, various regions in the world

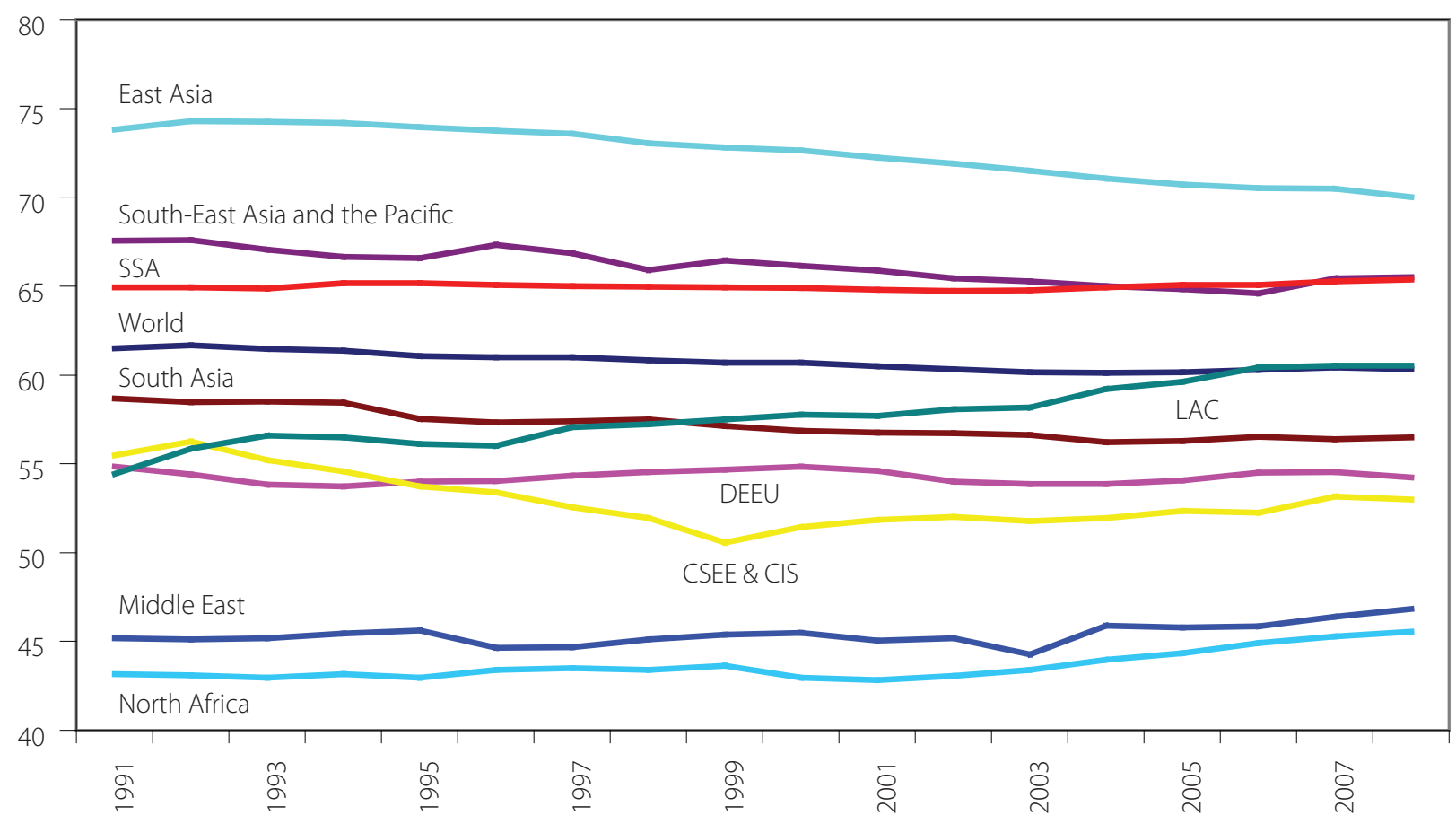

Source: ILO , Trends Econometric Models, July 2009.

Abbreviations: SSA, Sub-Saharan Africa; LAC, Latin America and the Caribbean; DEEU, Developed Economies and the European Union; CSEE \& CIS, Central and South Eastern Europe and Commonwealth of Independent States.

low female participation in the labour force at the beginning of the 1990s. At the global level, we notice two opposite trends, namely an increased ratio for female labour force participants and a decline of male participation (figure 2). The first trend can be ascribed to changes in customs and norms, and the second more to economic effects.

\section{The changing pattern in production}

The second trend is the changing pattern in production. For the world as a whole, the percentage of employment in the service industry has risen from 33.6 per cent in 1991 to 43.8 per cent in 2008. High service sector share in employment had already prevailed in developed countries, the Middle East, and North Africa, where we consequently see small increases of around 9.5, 2.5, and 2 percentage points, respectively; however, massive increases in this share took place in East Asia, where it almost doubled from 19.5 to 35.7 per cent, and in South Asia, where it increased from 23.6 to 30.1 per cent.

Some analysts interpret the increase of employment in the service industry as an indication of a post-industrial society and an important indicator of progress in development. But this interpretation fails to recognize that the service industry encompasses a wide range of activities, from hawking and peddling in the street to sophisticated financial services. Therefore a better indicator of development for developing countries is the size of the manufacturing sector. Here we notice a different trend over the last two decades. At the global level, the share of employment in industry has hardly changed between 1991 and 2008, remaining at 21.5 per cent. But there are again important regional differences. The most dramatic increase is in South-East Asia and the Pacific, where the share increased from 12.7 per cent in 1991 to 19.4 per cent in 2000, and in South Asia where it increased, over the same period, from 15.4 to 22.4 per cent, thereby almost 
Figure 2: Male employment-to-population ratio, 1991-2008, various regions in the world

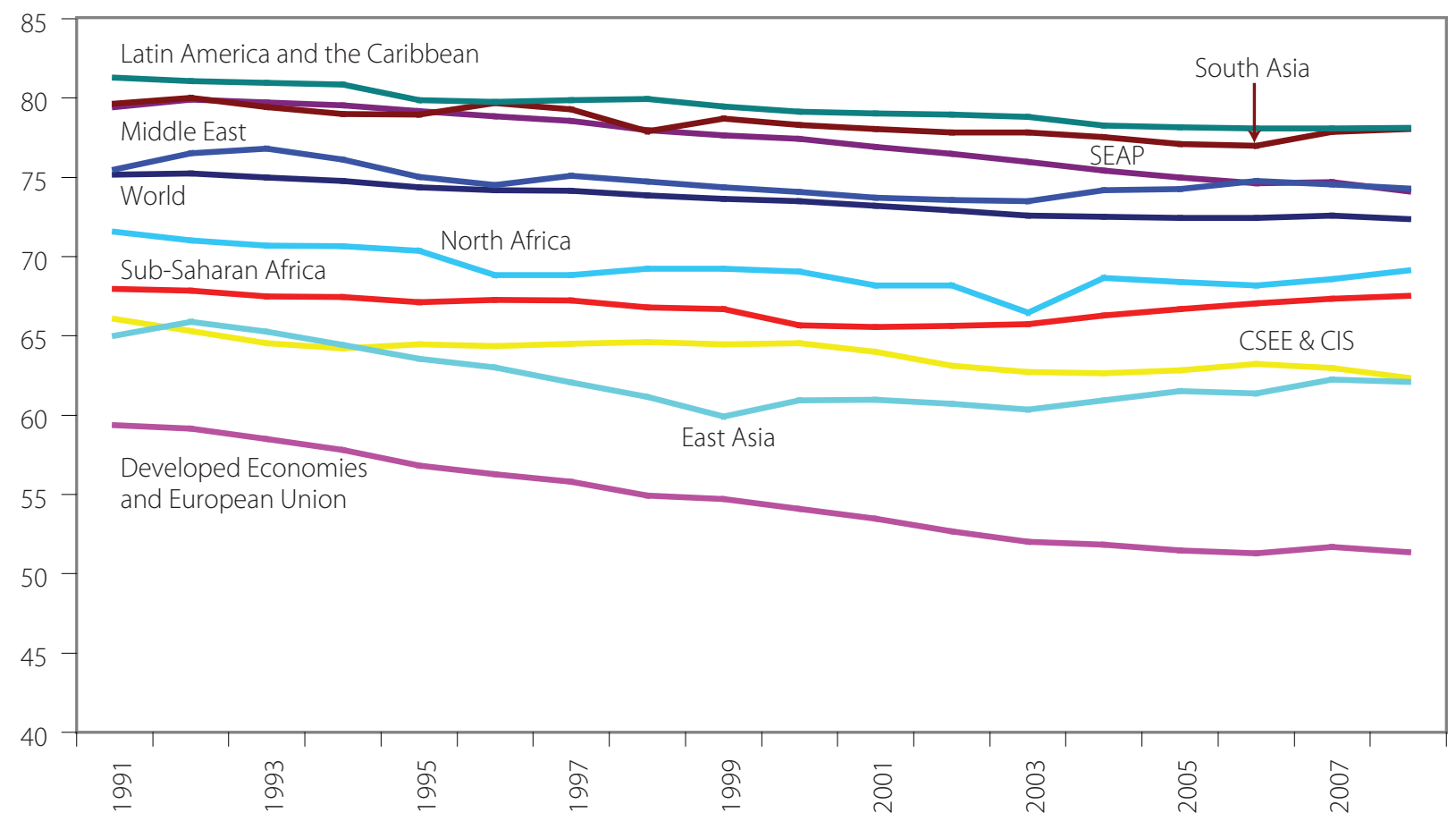

Source: ILO , Trends Econometric Models, July 2009.

Abbreviations: SEAP, South-East Asia and the Pacific; CSEE \& CIS, Central and South Eastern Europe (non-EU)

and Commonwealth of Independent States.

Figure 3: Percentage of employment in services, 1991-2008, various regions in the world

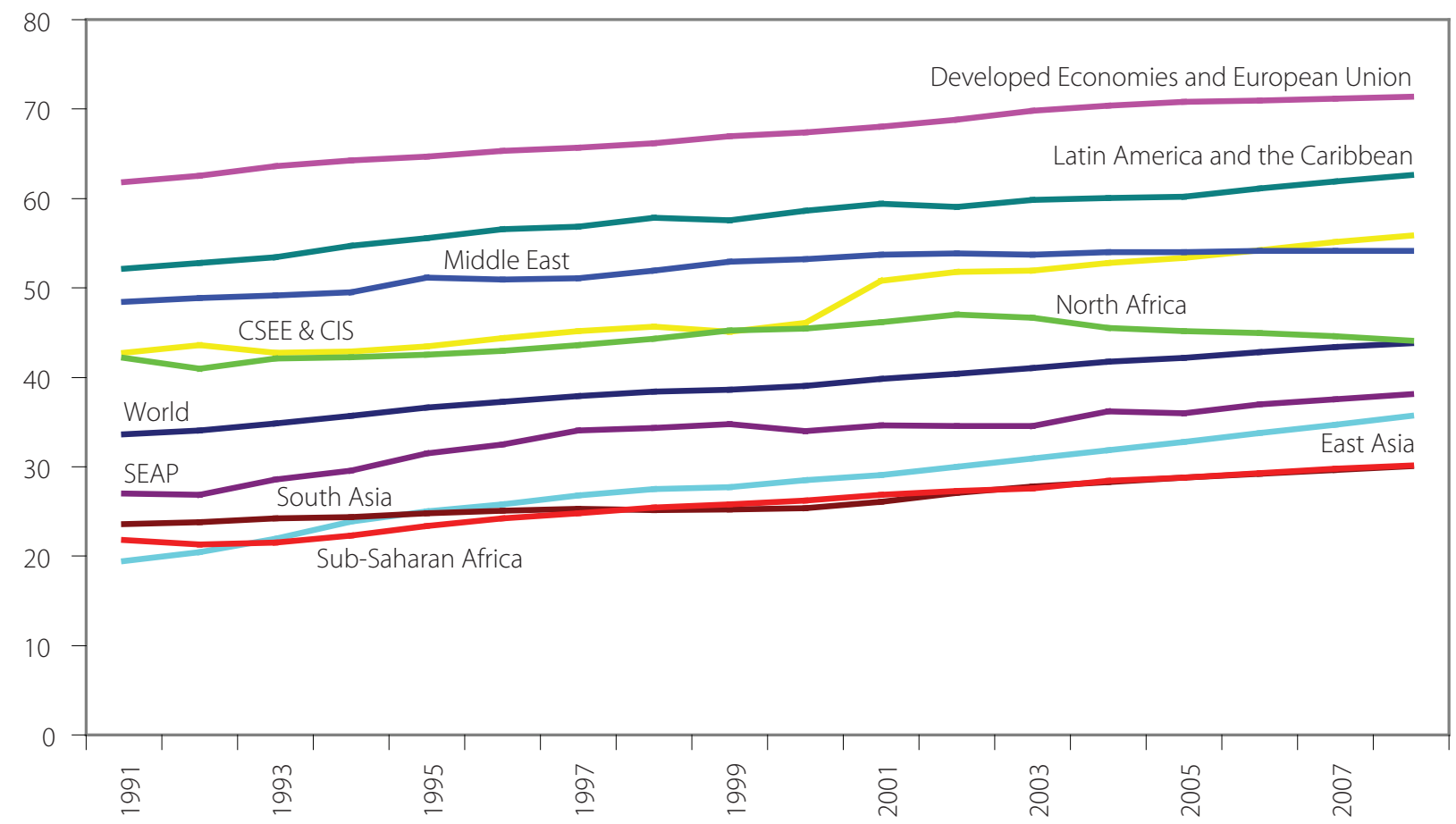

Source: ILO , Trends Econometric Models, July 2009

Abbreviations: SEAP, South-East Asia and the Pacific; CSEE \& CIS, Central and South Eastern Europe (non-EU) and Commonwealth of Independent States. 
Figure 4: Percentage of employment in industry, 1991-2008, various regions in the world

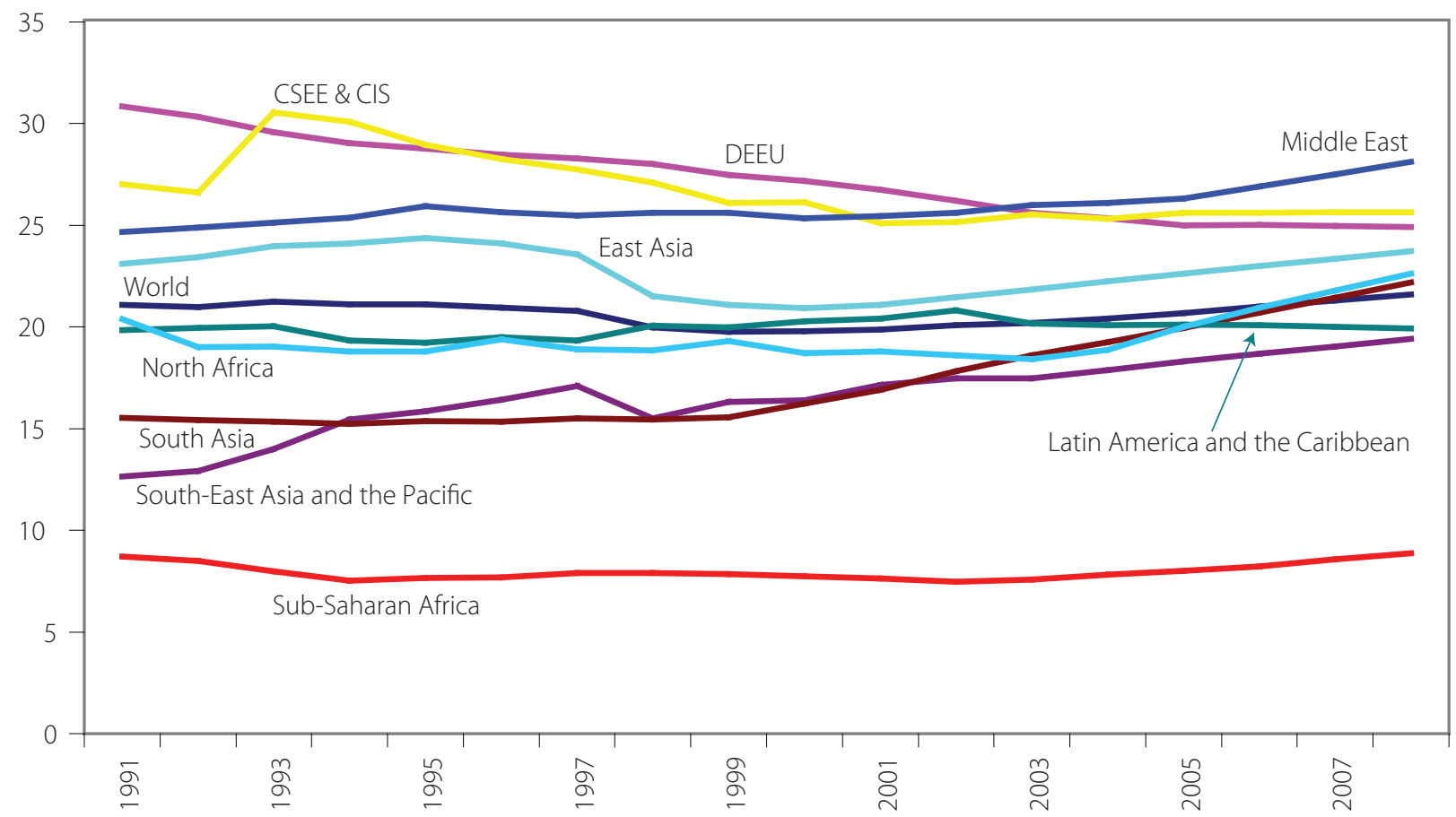

Source: ILO, Trends Econometric Models, July 2009.

Abbreviations: CSEE \& CIS, Central and South Eastern Europe (non-EU) and Commonwealth of Independent States;

DEEU, Developed Economies and European Union.

reaching the share in East Asia, which has remained more or less constant over the period (around 23.5 per cent, with a dip of 3-4 percentage points around 1998 owing to the Asian crisis). Noticeable are the very low and stagnant share in sub-Saharan Africa (at around 8.5 per cent) and a declining share in North Africa.

It should be noted, however, that the share of employment in industry can lead to an underestimation of the level of progress in industry. As Rada and Taylor (2006) observe, industry often has high productivity (or a low employment-value added elasticity). An important issue is therefore not only the size of employment in industry but also how the surplus generated in the industrial sector is used for reinvestment and how it is distributed throughout the rest of the economy.

\section{The "precarization" (casualization) of labour}

A third noticeable trend over the last 20 years is the "precarization" (casualization) of labour, or the increase of non-standard forms of employment. Contrary to what has been argued by some, this is not only the case for workers in developing countries, but applies equally for workers in developed countries. Precarization of workers in developed countries is manifest by changes in employment status, replacement of traditional labour contracts by outsourcing contracts, more flexible work arrangements, an increase in part-time work, etc. In developing countries, the precariousness is most clearly manifest in the existence of a pervasive "informal sector" in the economy or the "informal economy". ${ }^{5}$ This phenomenon is not restricted to poor developing countries, as figure 5 shows.

5 It has become common to speak about the "informal economy" rather than the "informal sector" as, increasingly, informal activities take place within established enterprises. It would thus be a misnomer to continue to speak about the informal sector. 
Figure 5: Informality and economic development

(average rate of informal employment, in percentage)

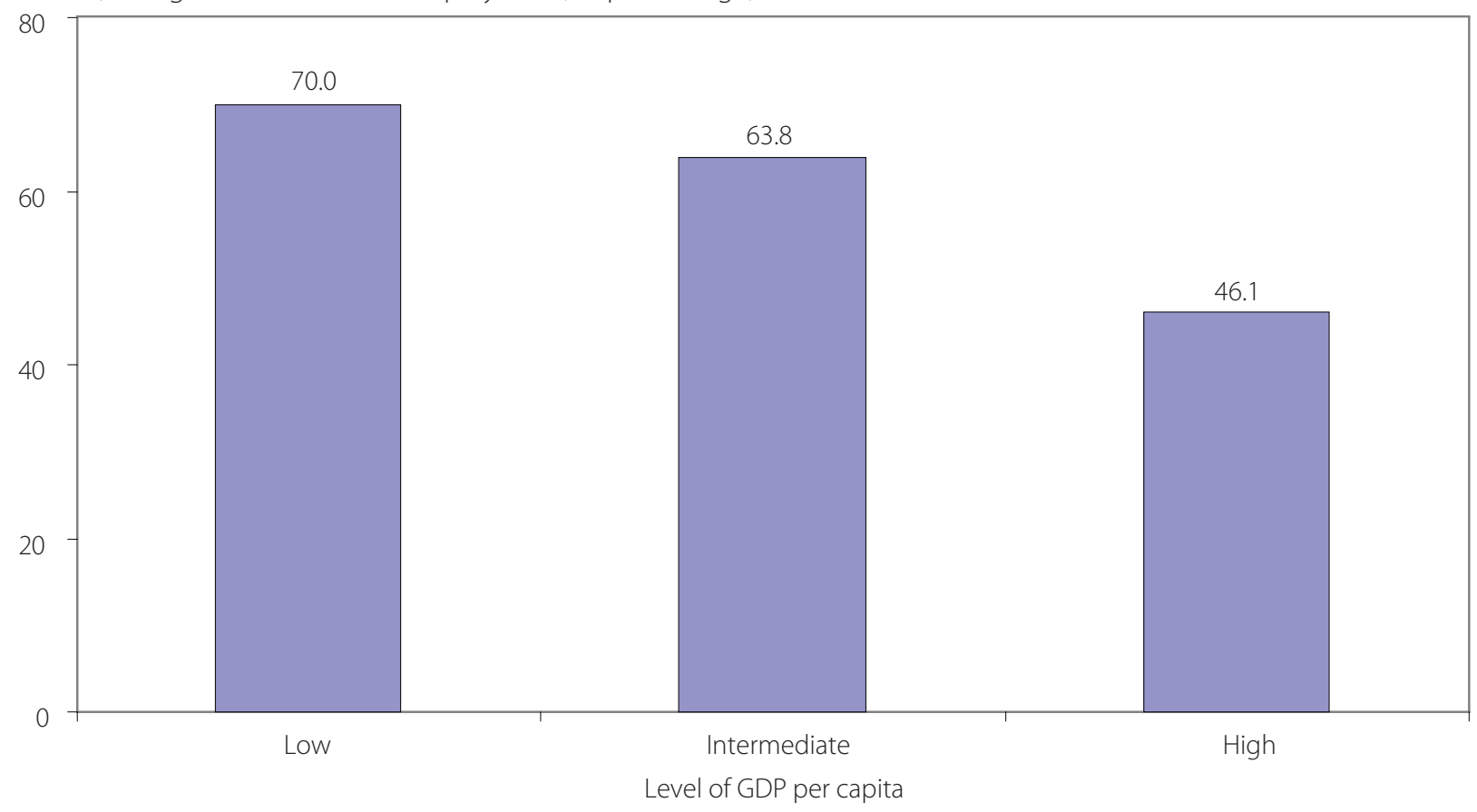

Source: ILO, Globalization and informal jobs in developing countries, 2009.

Note: The graph plots deciles of GDP per capita levels (in PPP) against the average size of the informal sector in the informal employment database used for this report.

The existence of the informal economy is partly related to the changes in the structure of employment: Especially for the poorer regions, the increase of employment in the service sector reflects an increase in the share of workers engaged in informal activities. Figure 6, obtained from a recent OECD publication, clearly indicates this pervasiveness of the informal sector in Latin America and South-East Asia. Despite increases in per capita income in these regions, quite substantial in the case of Asia, the size of the informal sector has increased, rather than declined.

Figure 7 shows that, despite the limited data available, we can nevertheless infer for all developing regions in the world an increase in the absolute number of workers employed in the informal sector; for two out of three regions, the relative share of informal workers in total employment has also increased.

There are, however contradictory explanations of the pervasiveness of the informal sector. Some (for example, Maloney, 2004) argue that the size of the informal sector is determined by the degree of labour market inflexibility. According to them, the more inflexible the labour market, the greater the avoidance of employers and workers to act in an informal manner. Others (for example, Kucera, 2008) argue that the major cause of informal sector activities is the lack of formal jobs. This interpretation has gained ground in the International Labour Organization (ILO), the Organization for Economic Cooperation and Development (OECD) and other United Nations organizations.

There is evidence of a clear link between the increase in non-standard work and income inequality (Rani, 2008), mainly owing to widening wage differentials between standard and non-standard jobs. Some would explain this by the low education level of those engaged in the informal sector, which is borne out by 
Figure 6: Informal employment and GDP in Latin America and South-East Asia

\section{Informal Employment and GDP in Latin America and South-East Asia}

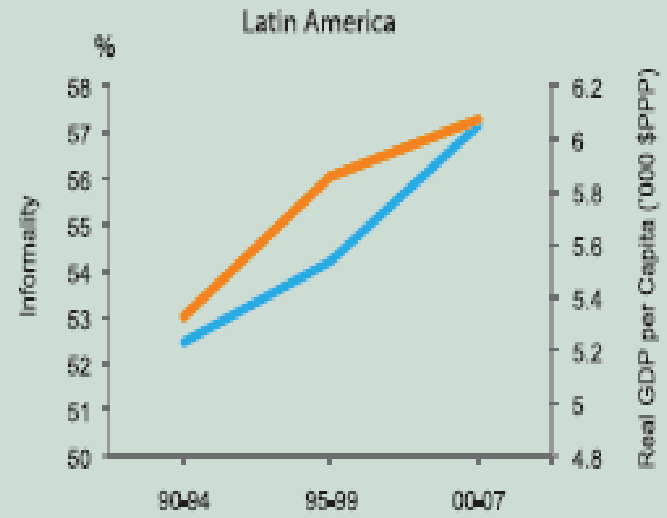

Share of informal employment in total non-agricultural employment $(\mathrm{OECD}, 2009)$

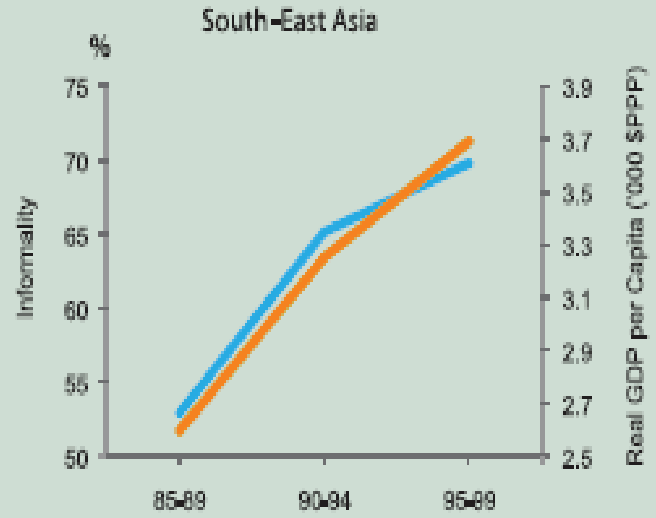

Real GDP per capita (Penn World Tables)

Note: Graphs based on un-weighted averages of countries in Informal is Normal? Towards more and better jobs (CECD, 2009).

Source: UNDP, Poverty in Focus, Jobs, Jobs, Jobs, The Policy Challenge, 2008.

Figure 7: Informal employment in different regions, 1990s-2000s

(relative to total employment, in percentage)

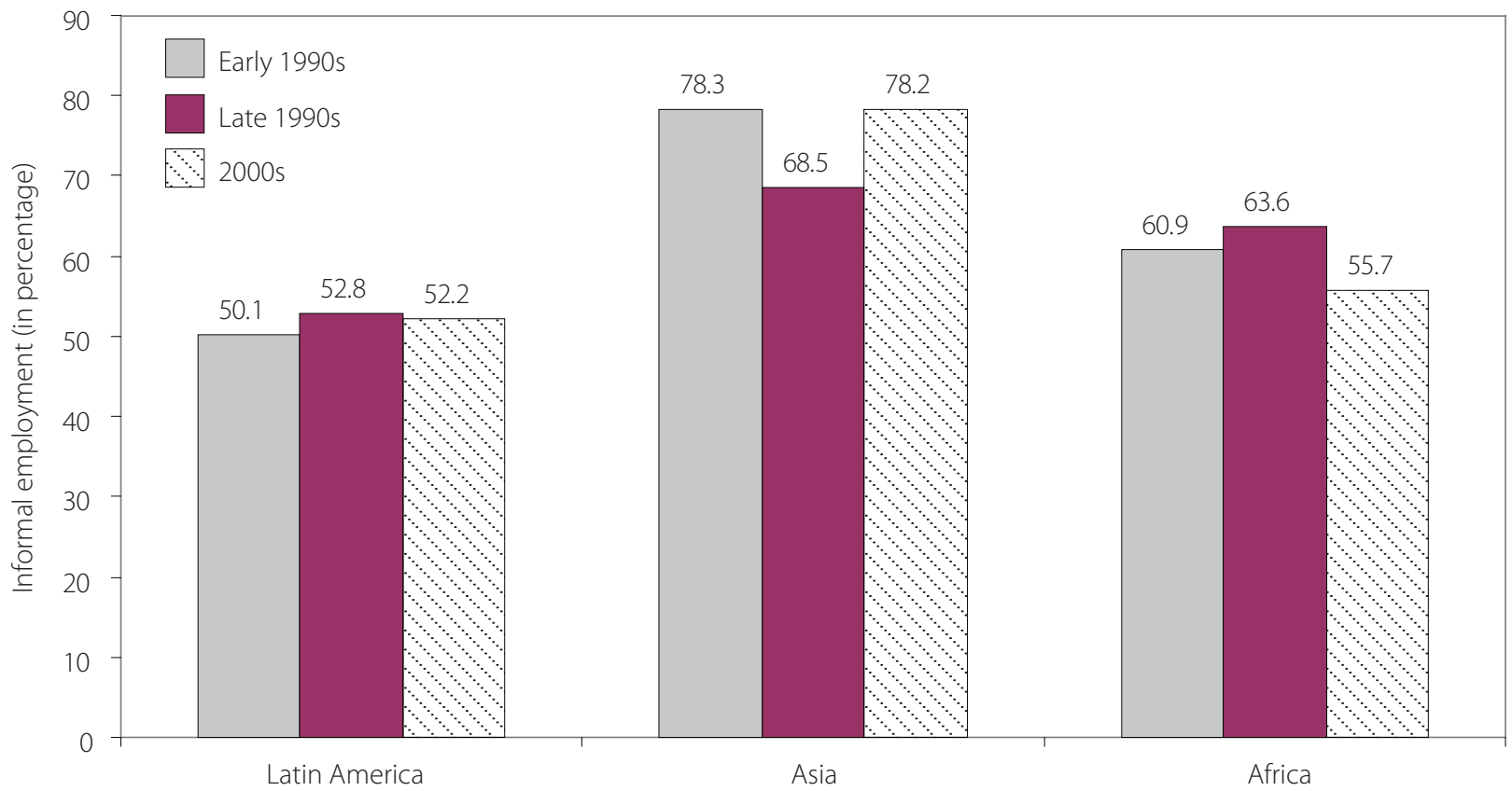

Source: ILO, Globalization and informal jobs in developing countries, 2009.

Note: Country groupings: (i) Latin America: Argentina, Chile, Colombia, Costa Rica, Ecuador, Mexico, Panama, Uruguay, Venezuela;

(ii) Asia: China, India, Indonesia, Pakistan, Sri Lanka, Thailand; (iii) Africa: Botswana, Cameroon, Egypt, Ethiopia, Ghana, Kenya, Malawi,

South Africa, Tanzania, Zambia, Zimbabwe. 
statistics. But it is most likely the type of job rather than educational attainment which drives inequality. An increase in education levels will result in better educated workers in the informal economy without a major decline in wage inequality in the absence of newly created formal jobs.

\section{Declining wage share and growing wage inequality}

A fourth trend, which is partly related to changing sectoral patterns and informalization of employment, is the declining wage share and the growing wage inequality seen in several regions around the world.

ILO (2008) reports that the wage share declined over the period 1995-2007 in two thirds of the developing countries, including the major ones. The only exception was the Latin American region, where some countries witnessed an increasing wage share. The ILO report attributes the declining wage share to increasing trade and globalization and confirms earlier research findings (see Diwan, 2001 and Harrison, 2002) that, contrary to the conventional wisdom that sees the labour share in GDP as being relatively constant, the proportion of GDP that goes into wages and other labour income is variable over time. Using a data set from 1960 to 1997, Harrison (2002) splits her sample (of over 100 countries) into two even groups (based on 1985 GDP per capita). Her data show that, in the group of poorer countries, labour's share in national income fell on average by 0.1 percentage points per year from 1960 to 1993 . The decline in the labour share accelerated after 1993 , to an average decline of 0.3 percentage points per year. In the richer sub-group, the labour share grew by 0.2 percentage points prior to 1993 , but fell by 0.4 percentage points per year thereafter. Thus there was a trend reversal for richer countries after 1993, and an acceleration of an already downward trend for the poorer sub-group.

Harrison (2002) tested for factors that could explain changes in labour shares, combining detailed national accounts data from the United Nations with measures of trade openness, capital account restrictions and capital flows. Overall, the results suggest that changes in factor shares are primarily linked with changes in capital/labour ratios. However, measures of globalization (such as capital controls or direct investment flows) also play a role. Harrison found that exchange rate crises lead to declining labour shares, suggesting that labour pays a disproportionately high price when there are large swings in exchange rates (that is, wages are more severely affected than GDP). Capital controls are associated with an increase in the labour share, an effect that Harrison attributes to the weaker bargaining position of capital vis-à-vis labour, if the cost of relocating production increases with capital control. Foreign investment inflows are also associated with a fall in the labour share. The weak bargaining position of labour under open capital accounts is also a causal mechanism explored by Lee and Jayadev (2005). They find that financial openness exerts a downward pressure on the labour share both in developed and developing countries for the period from 1973 to 1995. Harrison also finds that increasing trade is associated with a fall in the labour share. This result is robust across specifications. The above findings point to a systematic negative relationship between various measures of globalization and labour's share in GDP.

Diwan (2001) reports, based on a large sample of countries, an average drop in the labour share of GDP per crisis of 5.0 percentage points, and a modest catch-up thereafter. In the three years after the crisis, labour shares were still 2.6 percentage points below their pre-crisis average. Given the fact that most countries have undergone more than one crisis, the cumulative drop in the wage share over the last 30 years is estimated at 4.1 per cent of GDP, and is especially large for Latin America, where the share dropped by 6.7 per cent between the 1970s and the 1990s. The overall decline in the labour share is partly explained by what some call the ratchet effect: After an economic shock or a financial crisis, the labour share in gross national income (GNI) decreases (van der Hoeven and Saget, 2004). 
Figure 8: Changes in wage share in various countries, 1995-2007

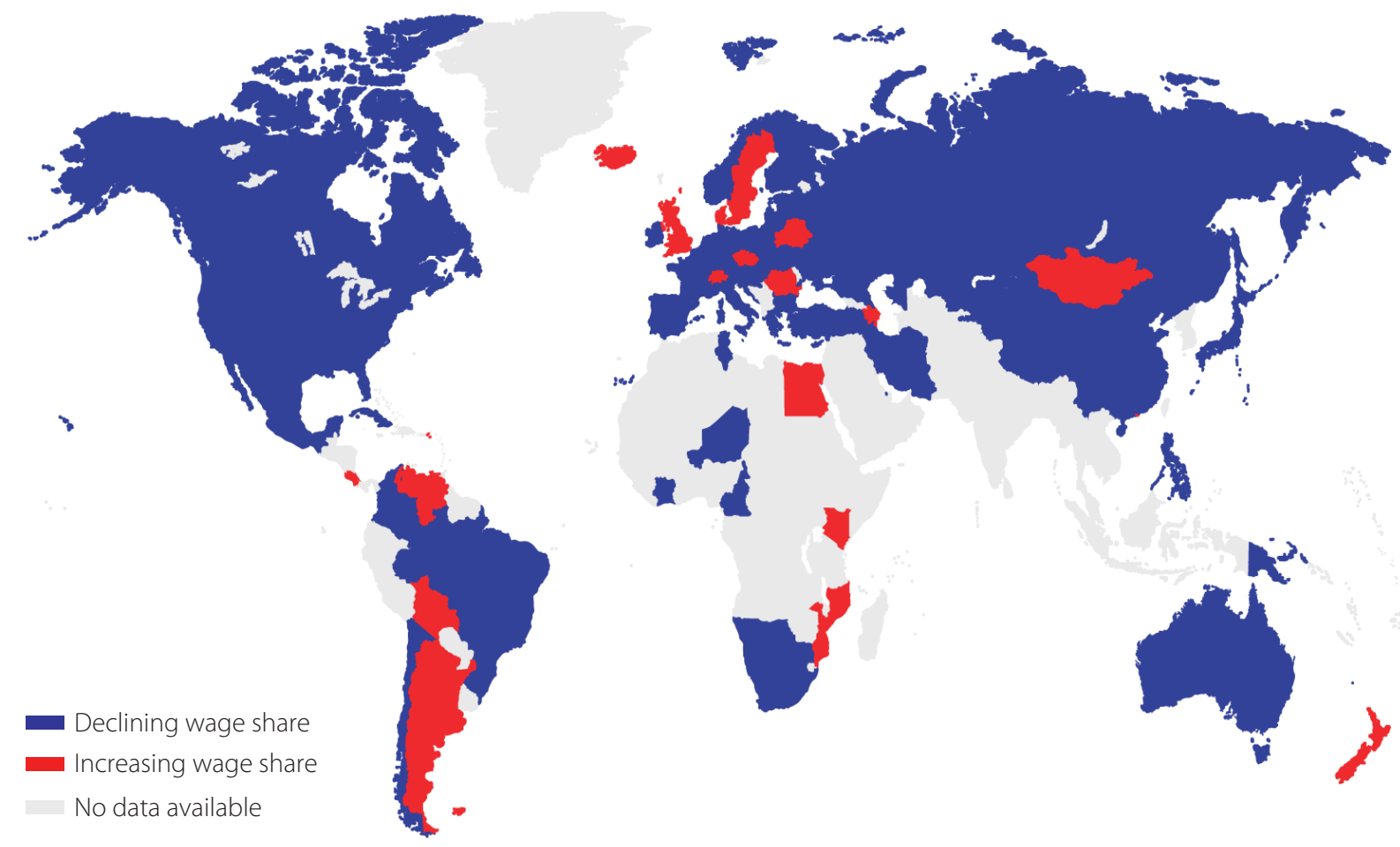

Source: ILO, Global Wage Report 2008/9.

Figure 9: Changes in wage inequality between top and bottom wage earners in various countries since 1995
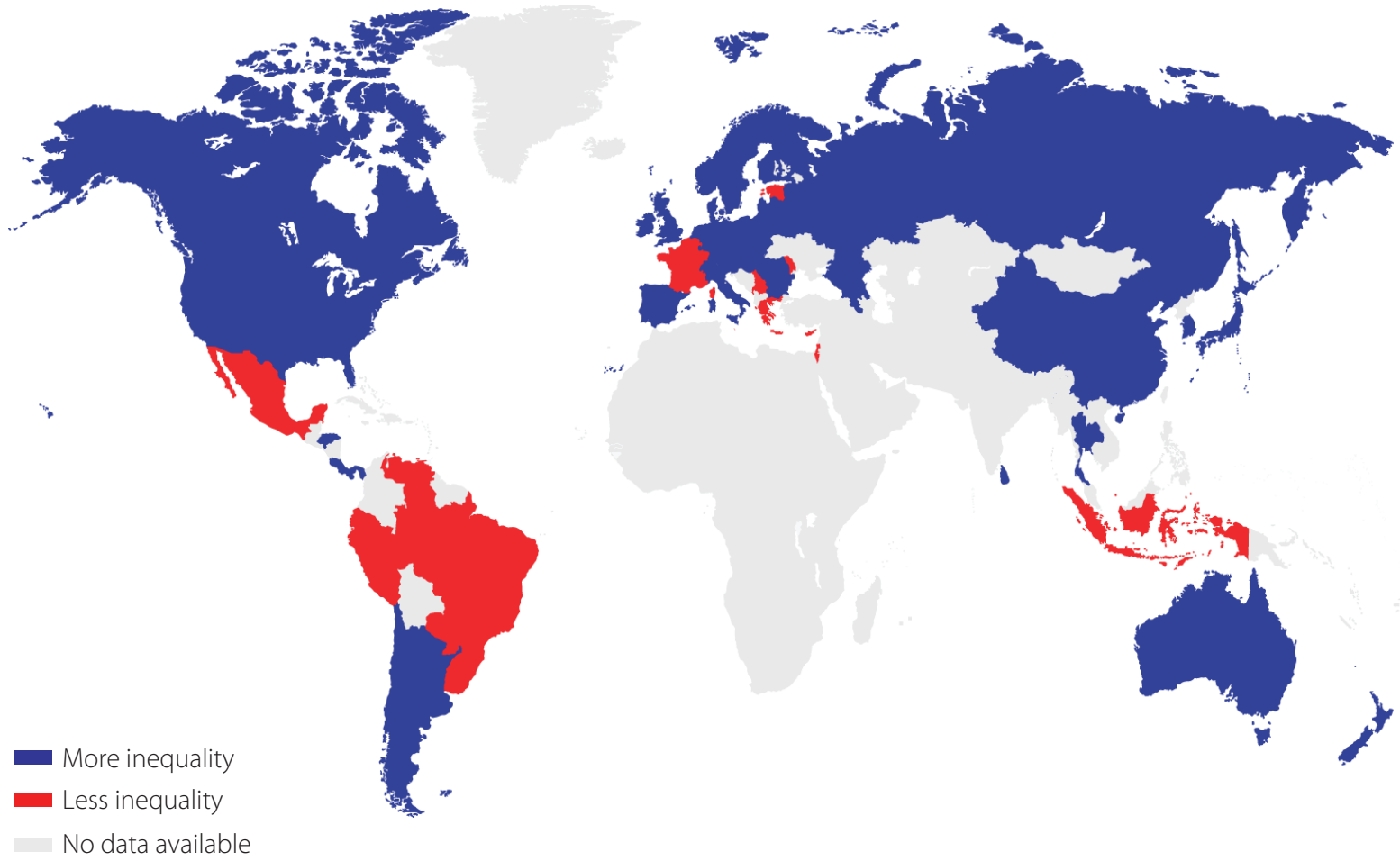
However, not only has the inequality between wages and other components of GDP increased but the distribution among wage earners has worsened. The ratio of the average wage of the top 10 per cent of wage earners (in relation to the bottom 10 per cent) is found to have increased in 70 per cent of the countries. Here, too, similar regional differences are observed - an almost uniform pattern for most regions, but mixed for Latin America.

\section{The internationalization of the production process}

A fifth noticeable trend over the last two decades has been the internationalization of the production process. Today, there are some 82,000 transnational corporations (TNCs) with 810,000 affiliates in the world. These companies play a major role in the world economy. For instance, exports from foreign affiliates of TNCs are estimated to have grown from about one quarter of total world exports of goods and services in 1982 to one third in 2007. And the number of people employed by these corporations has increased fourfold since 1982, standing at about 77 million in 2008, and implying a much faster rate of growth than that of the labour force. These TNCs are dominated by a smaller number of large firms. The largest 100 TNCs account for 11 per cent of total employment by TNCs and for about 4 per cent of world GDP. Over the last 15 years, the largest TNCs have undergone a rapid process of internationalization. There has also been a progressive increase in the proportion of companies operating in the service sector and of firms based in developing countries. ${ }^{6}$

Figure 10: Annual growth of employment, value added and exports by transnational enterprises, 1986-2007

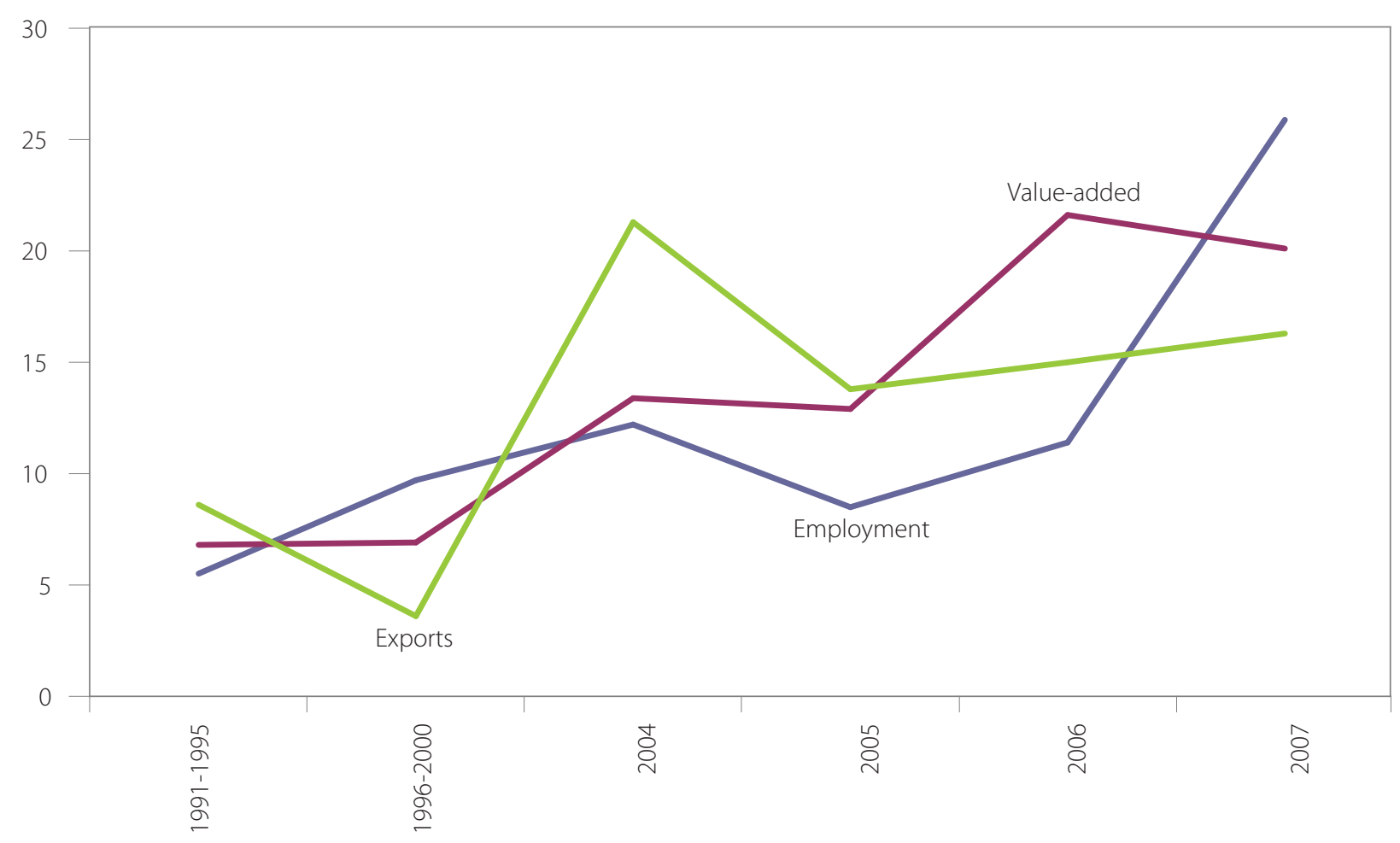

Source: UNCTAD, World Investment Report 2009, table 1.6.

6 UNCTAD, World Investment Report 2009, p. 17-18. 
Figure 11: Migrants as a percentage of population, 1960 and 2005

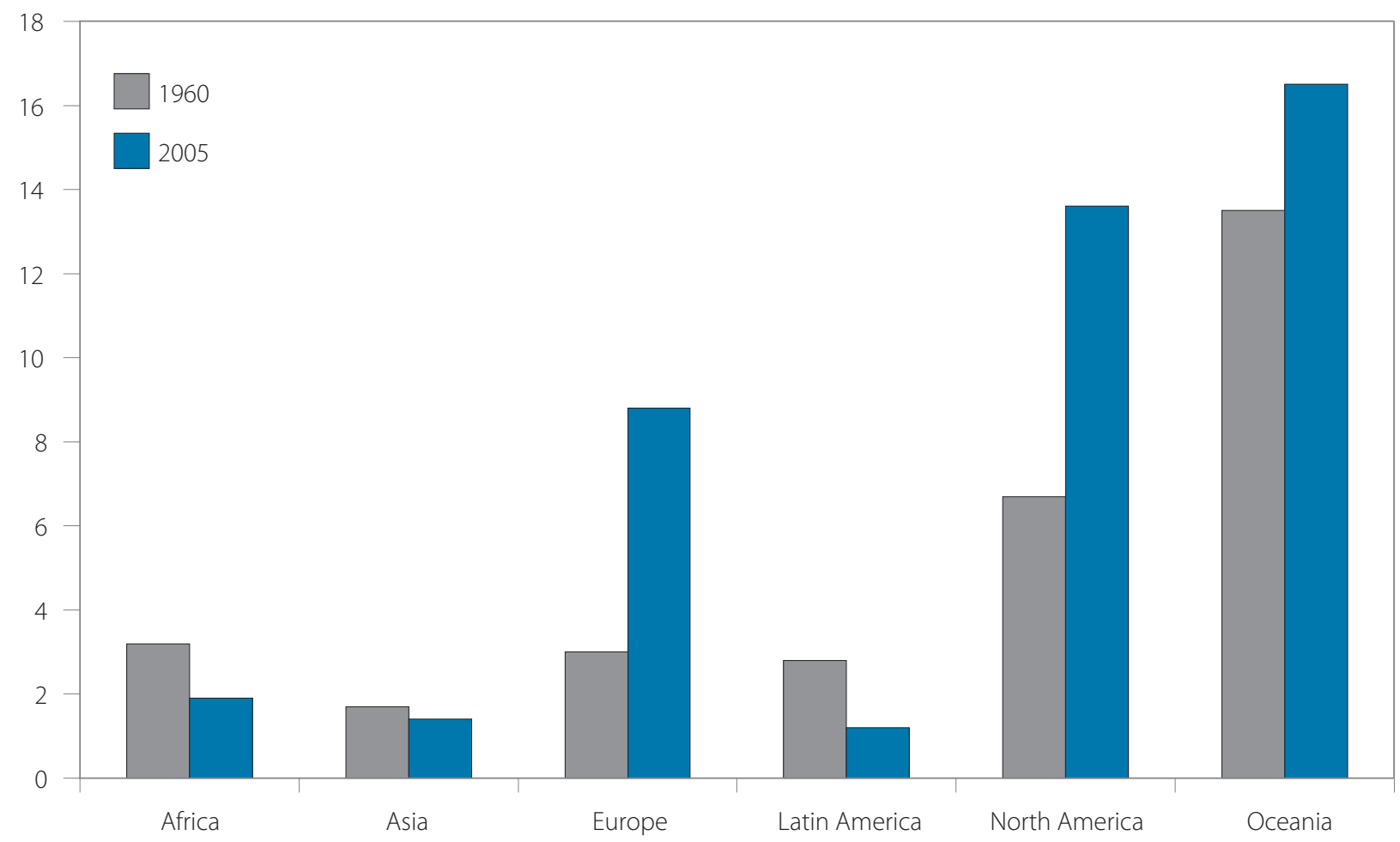

Source: UNDP, Human Development Report 2009, Statistical annex table 1.

\section{International migration}

A sixth noticeable trend is international migration. Global figures for migration do not show a substantial change: In 1960, the stock of total migrants in the world population was 2.7 per cent, and in 2005 this percentage had not changed. ${ }^{7}$ This has led some commentators to argue that globalization is characterized by increased capital flows and increased flows in trade and services, but not by increased labour flows. However this characterization is misleading. An examination of more disaggregated figures (by region) clearly shows a growing trend in some regions. In Europe, the stock of migrants as part of the population increased from 3.0 per cent in 1960 to 8.8 per cent in 2005 . The same ratio increased from 6.7 to 13.6 per cent in Northern America, from 13.5 to 16.4 per cent in Oceania, and from 4.9 to 37.1 per cent in the Gulf States. By contrast, the ratio of the stock of migrants to the local population declined in Africa, Asia and Latin America as a whole. The increase in the share of migrants in the local population in developed countries is quite substantial, despite the severe restriction most of these countries have put on inward migration.

This increased level of migration is leading to tensions in countries of destination but is providing an increasing source of foreign exchange for the sending countries. Figure 12 indicates that for many developing countries remittances represent a much larger flow than development assistance. For example, in East Asia and the Pacific in 2007, in per capita terms, remittances stood at $\$ 34$ per capita compared with $\$ 5$ for official development assistance (ODA) flows. Analogous figures for Latin America and the Caribbean are $\$ 114$ and $\$ 10$, and for South Asia, \$33 and \$6. Only in sub-Saharan Africa was the per capita inflow of remittances $(\$ 26)$ lower than that of ODA $(\$ 39)$.

7 This figure excludes the former Soviet Union as after the independence of the former Soviet republics, remaining Soviet citizens are counted as migrants. 
Figure 12: Workers' remittances and compensation of employees as a percentage of GDP, various regions, 1988-2007

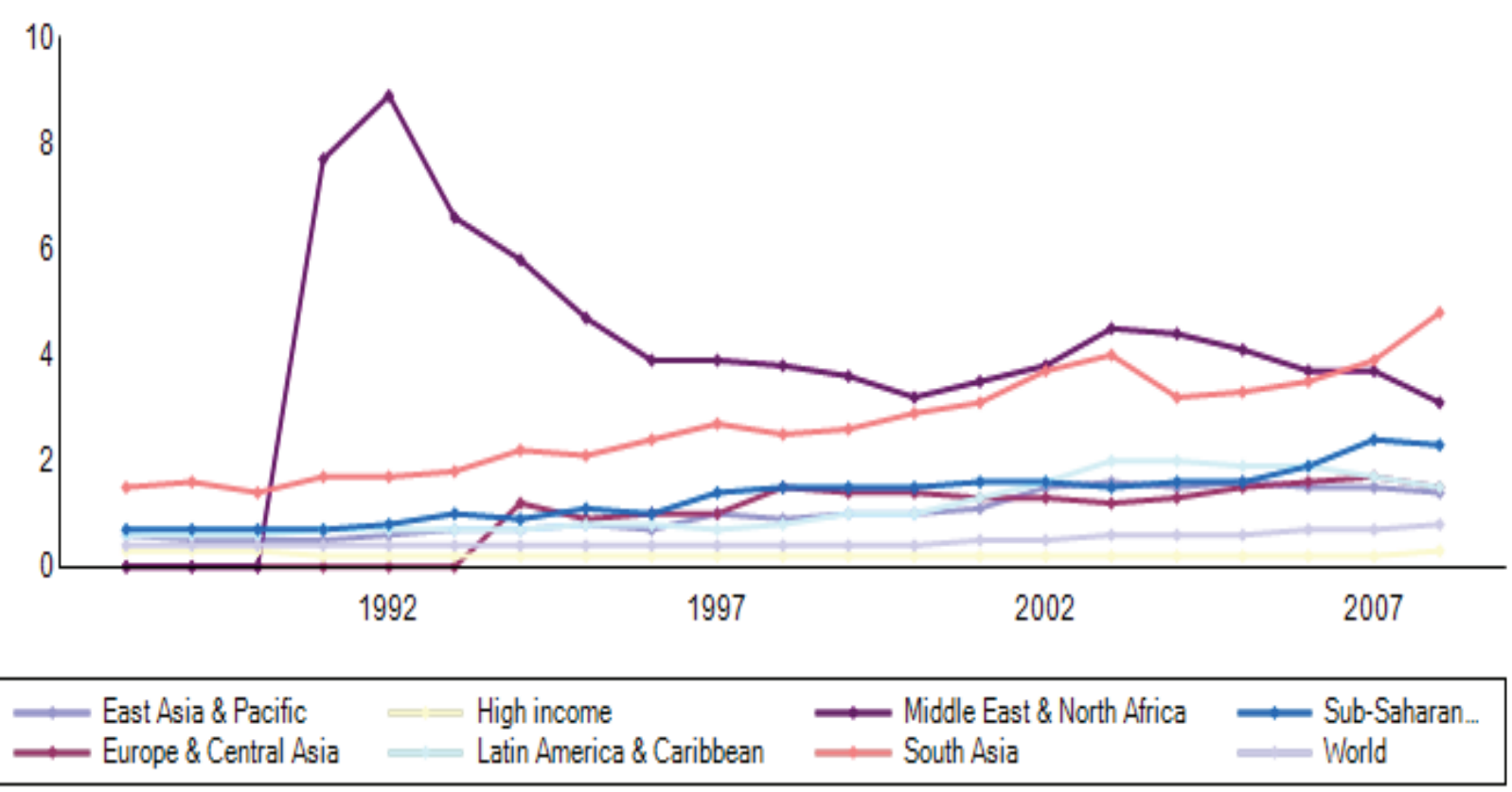

Scale: Units

Source: World Bank, 2009, World Development Indicators 2009.

Using a broad definition, the World Bank estimates that remittances to developing countries amounted to $\$ 166.9$ billion in 2005, compared to $\$ 85.6$ billion in 2000 and $\$ 31.2$ billion in 1990 (World Bank, 2005a, p. 88). Remittances are not only a rapidly growing source of external finance, but they are generally steady across years and not prone to sudden reversals of direction (Ratha, 2005). They tend to be counter-cyclical to crises in developing countries (that is, migrants send more money home to support their families) and hence help to smooth consumption volatility. However, the current financial and economic crisis engendered by the sub-prime mortgage crisis in the United States is leading to greater job losses than ever, in particular in industries such as construction that have a disproportionate share of migrant workers. This is creating the possibility of an adverse impact on remittances.

The six labour market trends described above-the declining employment-to-population ratio; the increase in service employment; the continuing high share of workers in the informal economy; the declining wage share and increasing income inequality; the growing importance of multinational enterprises; and the growing number of migrant workers in industrialized countries— give a general picture of increased "precarization" of many workers and their families, resulting in part from the ongoing process of globalization, including financial globalization. Freeman (2004) even argues that financial globalization affects employment and incomes of workers in developing countries more than trade liberalization does.

The next section therefore reviews in more detail the consequences of financial globalization, including its consequences for labour. 


\section{Financial globalization and labour}

\section{Introduction}

The current wave of globalization is characterized by the widespread adoption of policies for financial openness. ${ }^{8}$ Over the past two decades, many countries have liberalized their capital accounts (see Lee and Jayadev, 2005) and almost all policy measures related to foreign direct investment (FDI) favoured a more open regime. These measures have been adopted autonomously by some countries, including as conditions for loans' adjustment. The major expected result from financial openness was that it would allow developing countries to better utilize resources and to increase capital formation by stimulating FDI and other international capital flows, such as private portfolio investment. A more open national financial system was seen as a necessary complement to the lifting of impediments to international capital flows.

Capital has become more globally mobile as a result of these policy changes, especially since the mid-1990s. Worldwide, gross private capital flows (the sum of the absolute values of FDI, portfolio investment and other investment inflows and outflows) have exceeded 20 per cent of world GDP every year since 1998 and reached a new record of 32.3 per cent of GDP in 2005 - compared to less than 10 per cent of world GDP before 1990. Global FDI flows, a sub-category of private capital flows, also rose substantially during the 1990s. They peaked at 4.9 per cent of world GDP in 2000 and declined with the downturn of the early 2000s, but strongly rebounded before the current global financial and economic crisis. On average, global FDI flows doubled between the 1980s and the 1990s, and again in the years from 2000 to 2007.

In spite of this substantial increase in capital flows, the expected benefits have not materialized for many countries. During the surge in foreign capital flows since the mid-1990s, actual investment into new infrastructure and productive capacity stagnated. This can, in part, be attributed to the fact that much of FDI was spent on mergers and acquisitions (M\&As), rather than on investment into new factories or equipment that would have added productive capacity. ${ }^{9}$ Gross fixed capital formation (the most commonly used measure for physical investment) averaged 21.6 per cent of GDP in the 1990 s and 21.0 per cent in the years from 2000 to 2006. Hence, it fell well short of the level reached in the 1970s and 1980s. In fact, figure 13 below shows an overall declining trend in capital formation since the early 1970s. It is thus not surprising that, likewise, world GDP growth was slower in the 1990s and the 2000s than in previous decades (see figure 14 below).

Moreover, despite much excitement about the promise of "emerging markets", cross-border capital flows are still largely a phenomenon of developed countries. In 2005, gross private capital flows equalled 37.2 per cent of GDP in high-income countries, but only 12.7 per cent of GDP in low- and middle-income countries (World Bank, 2009a). While there was a positive balance between inflows and outflows for developing countries as a group, these flows have by and large bypassed the poorest countries since the early 1990s, as middle-income countries accounted for more than 90 per cent of the total. FDI is also highly concentrated among industrialized countries and a small group of middle-income countries. Low-income

8 Financial openness is used here as an umbrella term that includes both financial integration and financial liberalization. Financial liberalization, in turn, incorporates measures that effectively result in capital account liberalization. Included in financial openness are other elements such as reduced or different supervision and regulation of the banking sector and often a liberalization of the foreign exchange rate regime. For the standard presentation of balance of payments, see IMF (2004).

9 UNCTAD data show that the FDI boom was in part driven by M\&As. In 2007, the value of worldwide M\&As was US\$1,637 billion—some 21 per cent higher than during its previous peak in 2000. This compares to global FDI inflows of US\$1,833 billion in the same year. See UNCTAD, World Investment Report 2008. 
Figure 13: FDI and investment as share of GDP, world, 1970-2007

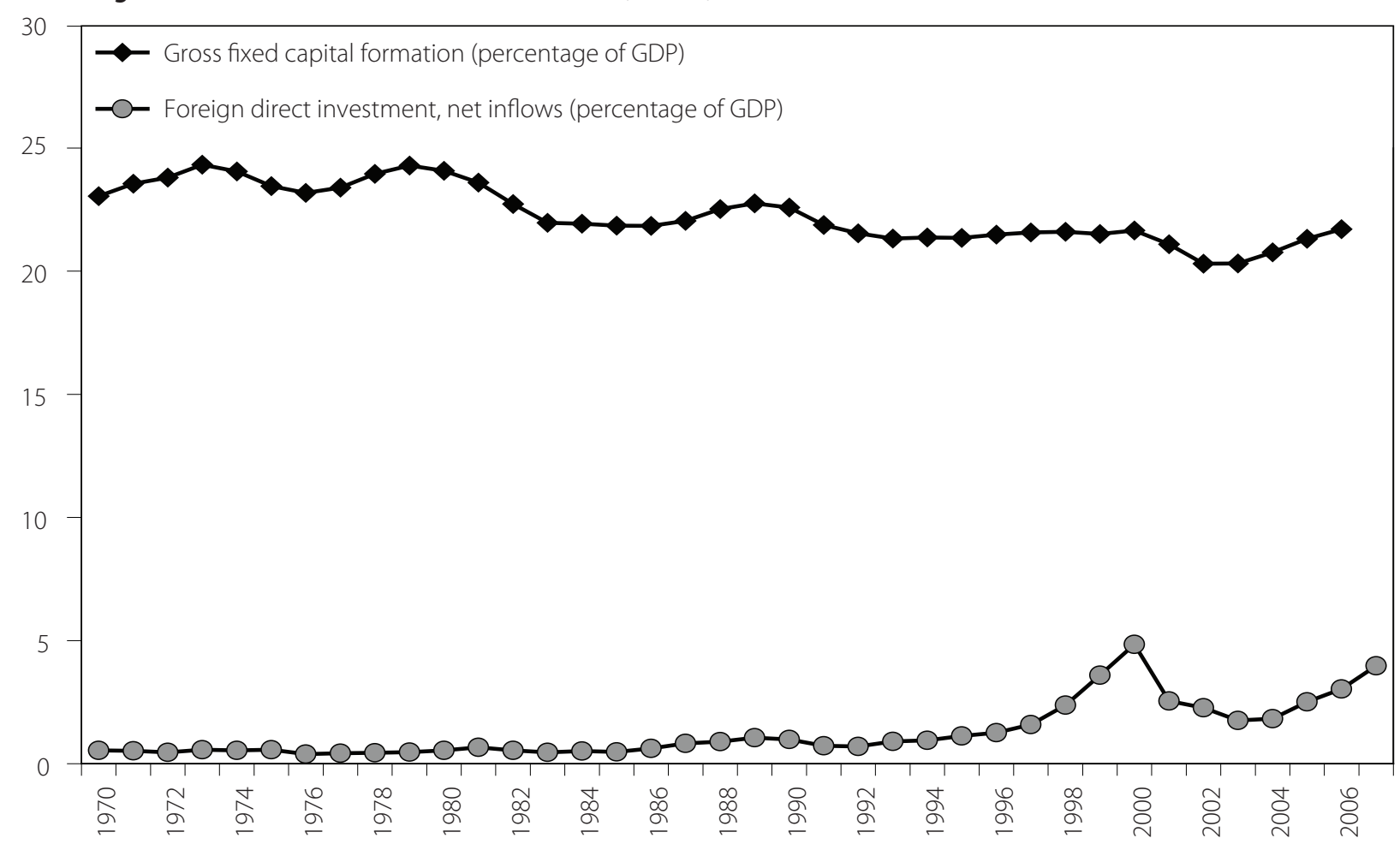

Source: World Bank, World Development Indicators, online database, as of May 2009.

Figure 14: World GDP Growth, 1961-2009

(annual percentage change)

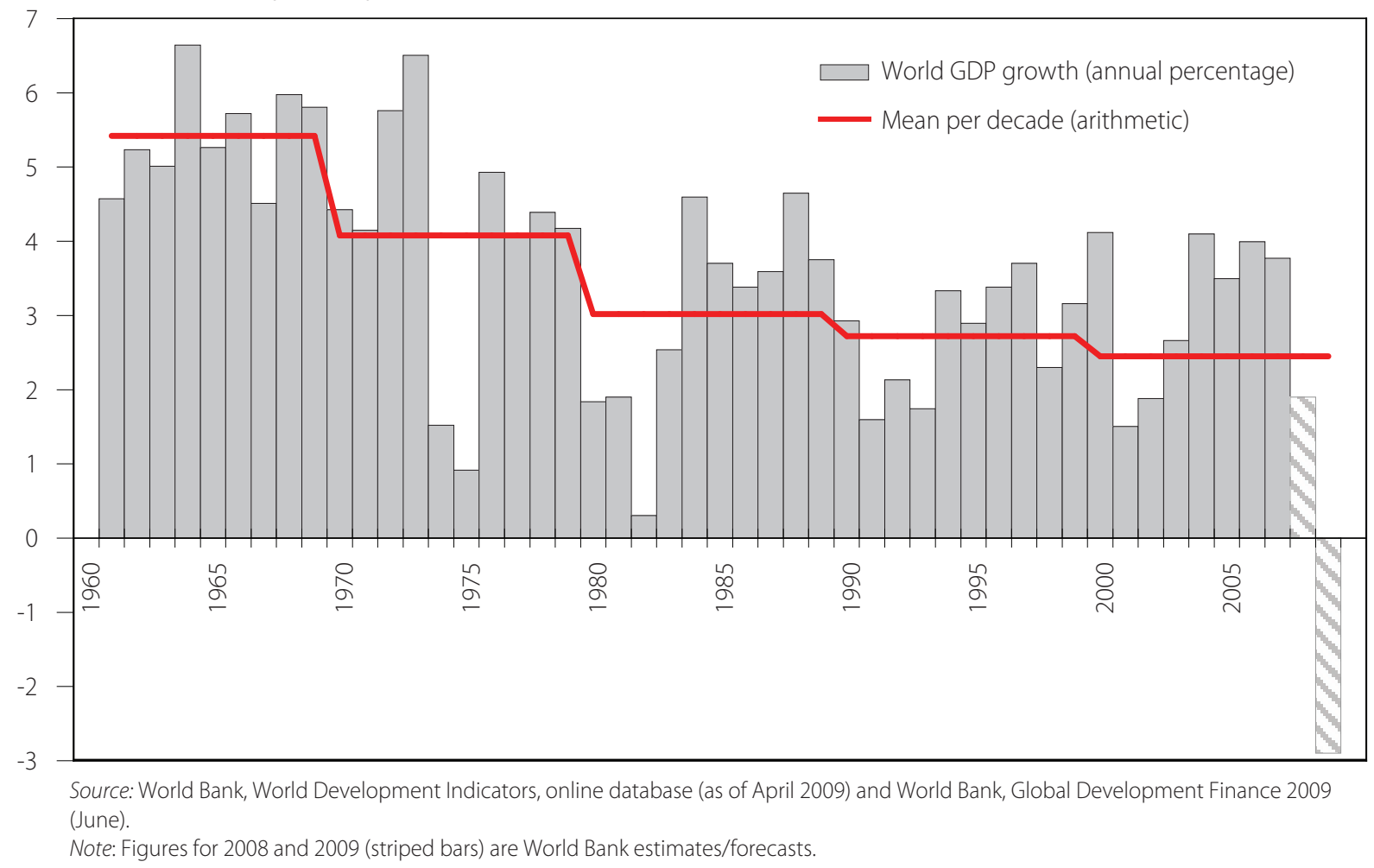


countries, to a large extent, still draw their foreign resources from remittances and ODA, which decreased over the 1990s and have only rebounded in the past few years. ${ }^{10}$

Meanwhile, international capital movements and their sometimes sharp reversals have led to greater economic volatility, a trend that has been well documented (Diwan, 2001; Prasad and others, 2003 and 2004; Cerra and Saxena, 2005). This volatility has led to more frequent financial and economic crises, predominantly in developing countries (see Easterly, Islam and Stiglitz, 2001; Singh, 2003). While the current financial crisis had its origins in the industrialized world, the initial hope that developing countries had effectively "decoupled" proved to be an illusion when the upheaval in capital markets and the economic downturn spread around the globe in a matter of months. Such crises have negative effects on growth, investment and incomes, not only in the short term, but also in the long run (Diwan, 1999 and 2001; Cerra and Saxena, 2005).

How does financial openness affect labour? The potential direct positive effect of capital flows on growth is manifest as countries gain additional resources that can be invested. However, there can also be an indirect negative effect on growth when financial liberalization forces countries to hold larger foreign reserves, thereby reducing consumption and/or investment and, hence, growth potential. If financial flows have, on balance, a positive impact on growth, this would be generally beneficial for labour, while slow growth is usually disadvantageous for labour. However, even in the case of fast or steady growth, the distributional impact of financial openness on different categories of labour needs to be taken into account. Labour might benefit less than is necessary for long-term institutional and human capital development and for growth of domestic consumption.

\section{Financial globalization, growth and employment}

It has proven difficult to establish a robust causal relationship between financial globalization and growth. ${ }^{11}$ A recent study by IMF researchers (Prasad and others, 2004) has confirmed the main findings of earlier studies, such as those undertaken by UNCTAD (2001), which finds that growth depends more on the quality of domestic institutions and careful macroeconomic management than on financial liberalization. Edison and others (2004) argue in the same vein and demonstrate that the findings of previous research (which found a positive association between capital account openness and growth) crucially depended on the country coverage, the choice of time periods and the indicator for capital account openness. They also find evidence for a suggestion that was first made by Rodrik (1998), namely that conventional indicators for capital account openness closely proxy the reputation of a country's government. If governance is controlled, capital account openness has no significant effect on economic performance (Edison and others, 2004).

10 ODA and official aid to all low- and middle-income countries actually declined through most of the 1990s, falling from US\$ 63.7 billion in current US dollars in 1991 to a low of US\$ 51.7 billion in 1997. The recovery thereafter brought levels back to US\$ 64.7 billion in 2002 and to US\$ 105.1 billion in 2007 . However, the increase is far smaller when adjusted for inflation. While it amounted to 1.7 per cent of GNI in recipient countries in 1991, the ratio fell to 0.7 per cent in 2007. See World Bank, 2009a, based on series "Official development assistance and official aid (current US dollars)" and "Aid (percentage of GNI)".

11 The conflicting results could in part be caused by differences in country coverage, but also by differences between the indicators employed in the literature. There is a crucial difference between "de jure" or "de facto" measures of financial openness. "De jure" openness includes abolishment or changes in rules and regulations concerning foreign capital, as it is often required as part of the conditionality for financial support by the international financial institutions. Many countries in Latin America fall under this category. By contrast, "de facto" openness relates to increases in a financial openness indicator, irrespective of whether rules have changed or not (India, China and some other Asian countries fall into this category). In the latter case, the causal relationship between financial openness and growth is more difficult to establish. Did openness lead to higher growth, or did higher growth induce financial flows and integration? Rodrik (2003) and Singh (2003) argue that the latter is the case, especially for India and China where growth induced greater financial integration. 


\section{Indirect growth effects through increased reserve holdings}

The financial crises of recent years have led many developing countries to build up foreign reserves. For some countries these reserves were created through a surplus on the current account, while others built up reserves through capital inflows which were not spent on foreign goods. Rodrik (2006) estimates the cost of increased reserve holdings to be 1 per cent of GDP, on average, for developing countries. While imposing costs on developing countries, increased reserve holdings are an indirect subsidy to the countries in whose currencies the reserves are held (see Stiglitz, 2000).

The trend has accelerated in recent years to a somewhat alarming level (see figure 15). Overall, reserves held by low- and middle-income countries were equal to 27.1 per cent of their GNI in 2007, compared to 6.8 per cent in the first half of the $1990 \mathrm{~s}$ - a fourfold increase. ${ }^{12}$ The increase took place in low- and middle-income developing countries alike, and across regions. Even a poor region like sub-Saharan Africa now holds foreign reserves equal to 17.9 per cent of its GNI, more than three times the ratio in the early 1990s. The trend is particularly strong in South Asia, East Asia and the Pacific. Even when China (the developing country with the largest foreign reserves) is excluded, there remains a substantial increase from an already high 15.0 per cent of GNI (1990-1994) to 27.6 per cent in 2007 for the rest of the region.

\section{Financial globalization, volatility, crises and employment}

Financial liberalization in developing countries is associated with increased GDP volatility and higher consumption volatility (Prasad and others, 2004; Kose, Prasad and Terrones, 2003; Levchenko, 2005). Kaminsky, Reinhart and Végh (2004) pointed out that the absence of sound financial regulation, both at the

Figure 15: Reserve holdings by developing countries, 1970-2007 (percentage of GNI)

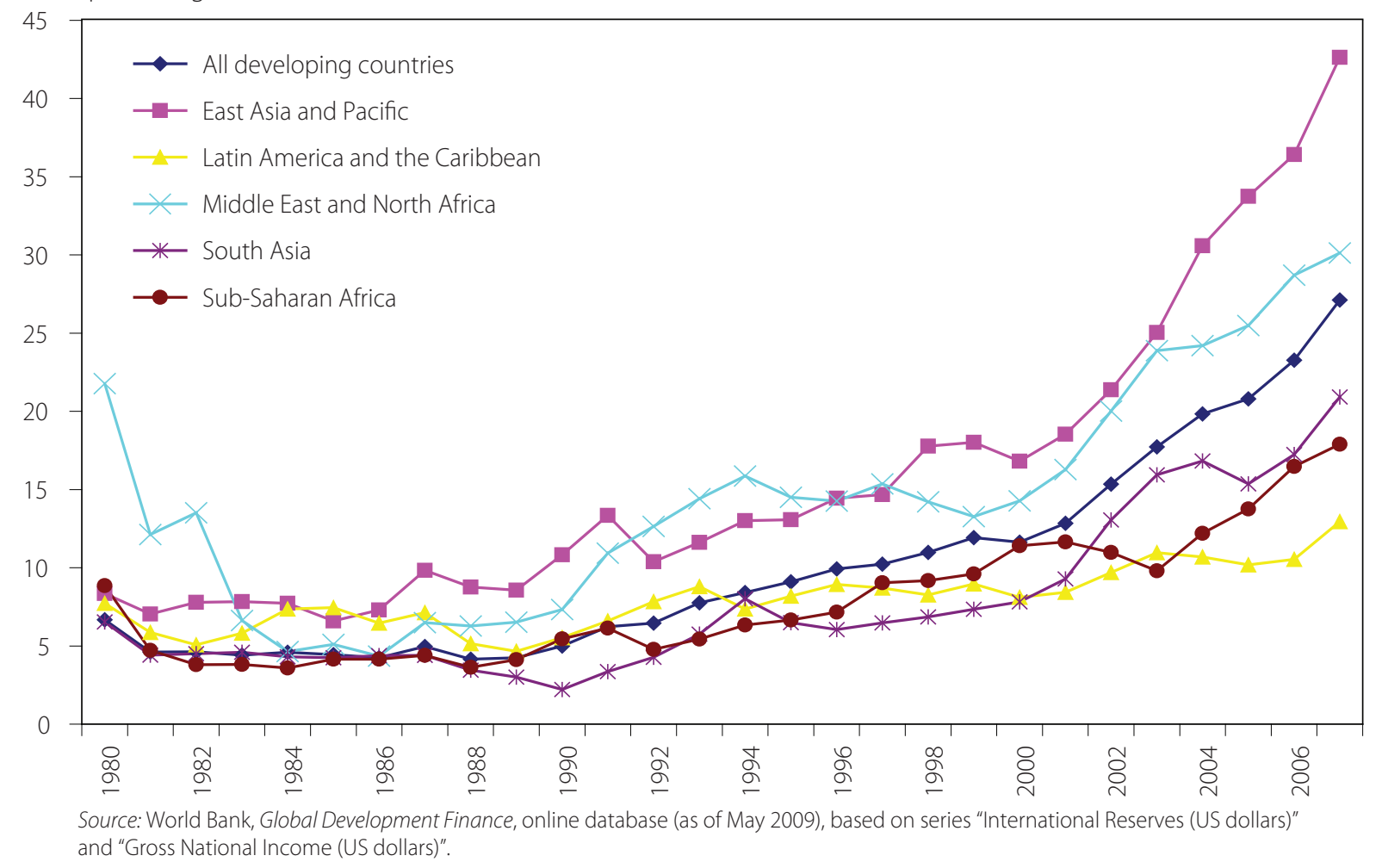

12 By contrast, foreign reserves have remained at under 5 per cent of GDP in industrialized countries (Rodrik, 2006. 
national and international levels, makes developing countries much more vulnerable to negative impacts of capital flows. When institutions with the ability to manage greater volatility are absent or not fully effective, the generally pro-cyclical nature of international capital flows (the "when it rains, it pours" syndrome) adds to the effects of fiscal policies, and, to a certain extent, also macroeconomic policies, which tend to be procyclical in most developing countries. Such behaviour deepens and prolongs a crisis.

Financial crises typically have a large impact on the real economy. Among the countries most affected by the East Asian crisis of 1997/98, GDP per capita fell between 2.6 per cent (Philippines) and 14.8 per cent (Indonesia). In Latin America, the Mexican crisis of 1994/95 led to a decline in incomes by 7.9 per cent, and the Argentinean crisis of 2001/02 reduced the country's per capita income by 16.5 per cent. A recent study by Hutchison and Noy (2006) documents that so-called "sudden stop" crises (a reversal in capital flows and a simultaneous currency crisis) have a particularly harmful effect on output-over and above that of "normal" currency crises. On average, they cause a cumulative output loss of 13 to 15 per cent of GDP over a three-year period.

The view that crises pose only a temporary setback is challenged by Cerra and Saxena (2005), who deconstruct what they call the "myth of recovery" by using panel data for broad datasets of countries. They document that recessions are typically not followed by high-growth recovery phases, either immediately following the trough, over several years of the subsequent expansion, or even over the complete subsequent expansion that follows a recession (figure 16). When output drops, it tends to remain well below its previous trend. Cerra and Saxena also find that frequent crises and instabilities interfere with the convergence between rich and poor countries:

Figure 16: Typical growth path after a financial crisis in rich and poor countries

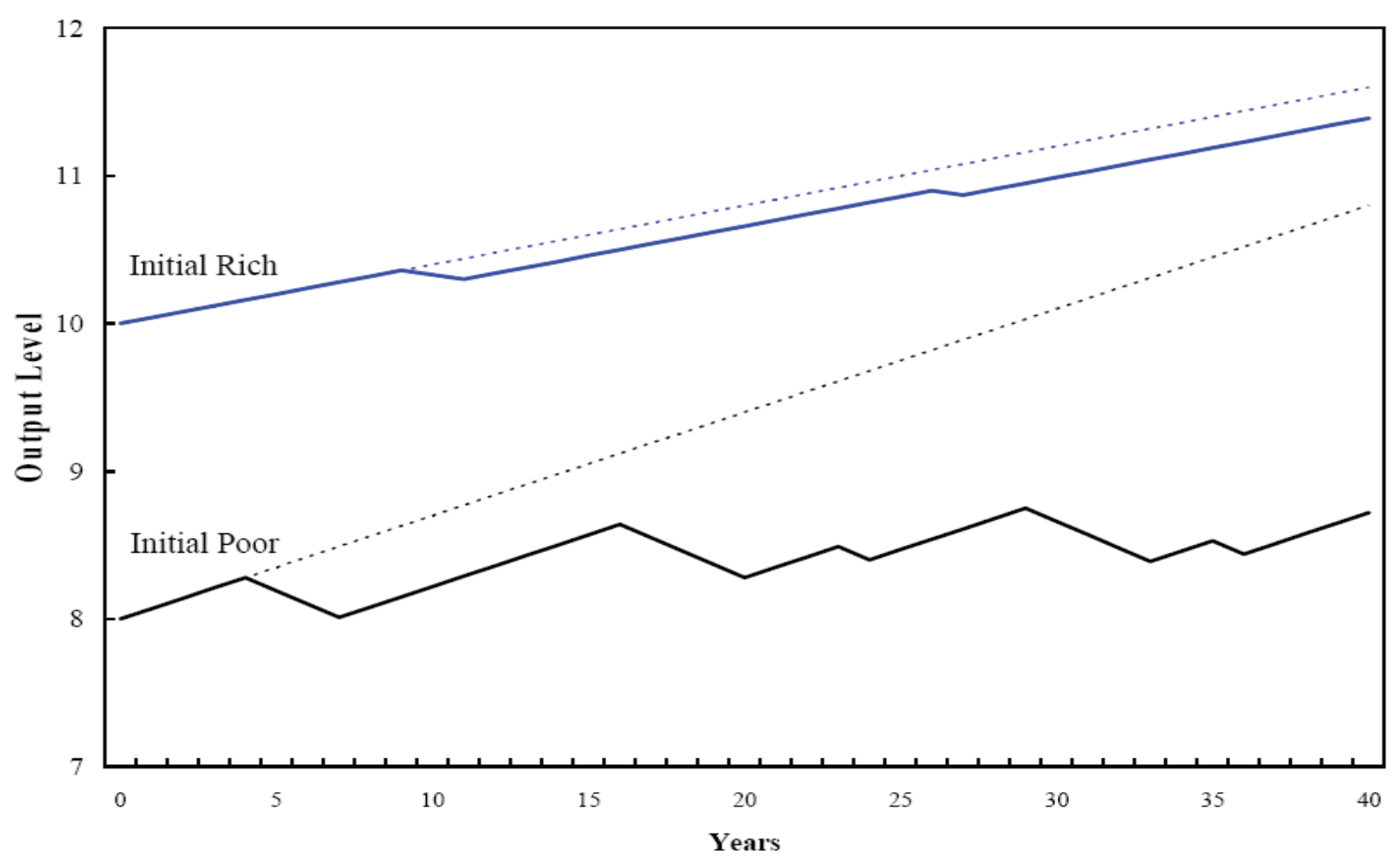

Source: Cerra and Saxena (2005). 
"Countries that experience many negative shocks to output tend to get left behind and their long-term growth suffers. Thus, while standard growth theory may work well in explaining expansion, a fruitful direction for future research would be to explain the proclivity to wars, crises, and other negative shocks." (Cerra and Saxena, 2005) ${ }^{13}$

Financial crises generally provoke both economic decline and social costs. These are most prominently felt in terms of rising open unemployment, falling employment-to-population ratios, falling real wages, or a combination of the above (see, for example, Lee 1998). Moreover, the social costs are usually felt longer than the economic impact: even when GDP per capita has recovered to pre-crisis levels, the other indicators usually lag behind (see World Commission on the Social Dimension of Globalization, 2004). This pattern can be observed in a majority of countries that were most affected by the financial crises of the past decade. We compare the situation before to that after a financial crisis for some of the most salient examples.

\section{Impact of financial crises on employment in Latin America and Turkey}

Latin American countries have experienced several periods of financial turbulence in recent years. The most prominent examples are the Mexican "Tequila crisis" during 1994/95 and the currency crisis in several South American countries in the aftermath of the East Asian and Russian crises. Following extensive liberalization policies in Mexico, financial inflows expanded rapidly in the early 1990s, but reversed in 1994. The peso devaluation of December 1994 (see Ibarra, 1999) brought the recently privatized, already fragile banking system into considerable difficulty as the peso value of foreign denominated debt soared. Similarly, the balance-sheet positions of companies which had accumulated debt in United States dollars deteriorated rapidly (see Carstens and Schwartz, 1998; Mishkin, 1999), which in turn led to a sharp fall in investment (Aguiar, 2005). Taken together, this can explain how a currency crisis rapidly turned into a crisis of the real economy and provoked a recession with an 8 per cent drop in per capita income in 1995. Unemployment, relatively stable at around 3 per cent before the crisis, started to increase during 1994 and reached 5.8 per cent in 1995, almost twice the pre-crisis rate. However, these figures mask the actual loss of jobs, since the share of informal employment rose from 30 per cent in 1993 to 35 per cent in 1995 (ILO, 2005). By 1997 Mexico had achieved its pre-crisis income level, with the unemployment rate lagging the economic recovery by one year. However the share of informal employment remained above its pre-crisis level.

Brazil experienced large foreign capital inflows from 1994 onwards, when the Real Plan had introduced a new stable currency (see Cinquetti, 2000). When investor sentiment swung suddenly after the Russian debt default of August 1998, Brazil responded by tightening its monetary policy in an effort to defend the exchange rate. Even though interest rates reached 40 per cent in late 1998, the capital outflows from Brazil were massive and the Central Bank allowed the real to devalue. The currency crisis, in combination with the recessionary impact of high real interest rates, led to a relatively modest decline of per capita income that was accompanied by an increase in unemployment from 7.7 per cent in 1997 to 9.6 per cent in 1999 (see figure 17). Despite the subsequent economic recovery, unemployment rates have hardly recovered, and remained close to 9 per cent in 2004 .

Like other emerging economies, Chile received large international capital inflows in the beginning of the 1990s. But unlike most other countries, Chile imposed controls on capital inflows in the form of

13 This is related to the point Rodrik (2003) makes, namely that policies for stimulating growth are different from policies to sustain growth and that frequent crises require frequent policy regime switches. 
Figure 17: Medium-term effects of financial crises on unemployment in several Latin American Countries
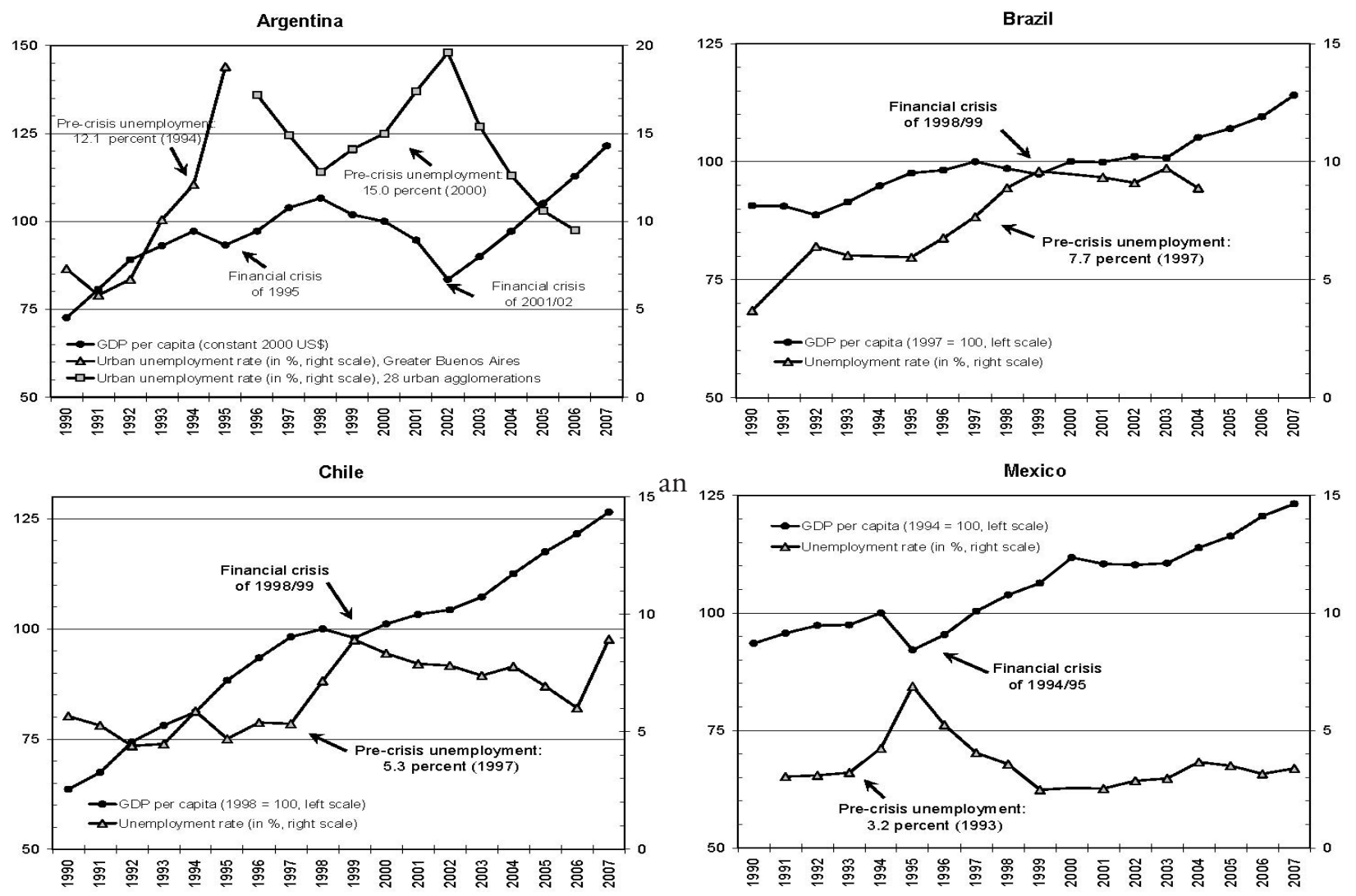

Source: World Bank, World Development Indicators, online database as of May 2009, series "GDP per capita (constant 2000 US dollars)"; ILO, Key Indicators of the Labour Market, 5th edition (2009).

Note: Unemployment data for Brazil exclude the rural population of Rondônia, Acre, Amazonas, Roraima, Pará and Amapá. Unemployment data for Argentina refer to Greater Buenos Aires (SIAL series) or to 28 urban agglomerations (LABORSTA series).

unremunerated reserve requirement (URR) ${ }^{14}$ Although it is uncertain whether this affected the overall amount of inflows, it did reduce speculative capital inflows: the share of short-term debt in total external debt fell from an already low level of 19.4 per cent in 1990 to 4.8 per cent in 1997-at a time when other countries increasingly relied on short-term financing (de Gregorio, Edwards and Valdés, 2000). At the onset of the Asian crisis, Chile was thus considerably less exposed to international volatility. The peso was also at the lower (appreciated) end of the exchange rate band at the time, leaving room for a relatively large devaluation within the band. However, the Central Bank feared that a depreciation could endanger the inflation target. Therefore, it defended the peso against growing pressure with a mix of monetary tightening and interventions on the foreign exchange market, before finally allowing the peso to float in September 1999 (Morandé and Tapia, 2002).

Solimano and Larraín (2002) argue that the Central Bank effectively prioritized "[1]ower inflation over higher growth and employment". The high interest rates had a recessionary impact, and unemployment increased from 5.3 per cent in 1997 to 8.9 per cent in 1999. While GDP per capita regained its 1998 level

14 The unremunerated reserve requirement was introduced in June 1991 and was in effect until June 1998. It acted like a tax on inflows and allowed for a differential between world interest rates and those in Chile, while keeping inflows under control (see de Gregorio, Edwards and Valdés, 2000). 
in 2000, unemployment fell only slowly and reached 6.0 per cent only in 2006. Solimano and Larraín (ibid.) discuss several hypotheses that could explain the sluggish employment performance, among them firm restructuring, continued job losses in small and medium enterprises (SMEs) and the noticeably slower rate of GDP growth after the crisis. They warn that unemployment could become a structural problem in Chile unless capital formation accelerates (ibid.).

The case of Argentina stands out, for the country went through two financial crises: in 1995, when investors withdrew capital following the Tequila crisis in Mexico, and again in 2001/02, leading to the collapse of a fixed exchange rate system (see Daseking and others, 2004). The first crisis caused only a relatively mild downturn, and, with considerable foreign support, pre-crisis income levels were again reached in 1996 (see Damill, Frankel and Maurizio, 2002). As in other countries, the unemployment rate (that covers only urban areas, in the case of Argentina) was still far above the pre-crisis level at this point, but it was approaching its 1994 level by $1998 .{ }^{15}$ A recession in 1998 sent unemployment rates rising again. Argentina therefore went into the 2001/02 crisis with an already high level of (urban) unemployment (15.0 per cent in 2000), that rose to almost 20 per cent by 2002 . More recent data indicate that a partial recovery had occurred by 2006, when unemployment fell below 10 per cent for the first time. Economic turbulence and the cumulative effects of two financial crises have thus caused a substantial unemployment problem in a country where unemployment rates had fluctuated around 5 per cent for most of the 1980s (ILO, 2005).

In Turkey, the frequency of crises was even higher than in Argentina. The country had liberalized its economy throughout the 1980s, but embarked on full capital account liberalization only in August 1989. Since then, capital flows have been highly volatile and have contributed to the repeated crises that affected the country in 1994, 1998/99 and 2001. As Demir (2004) argues, the country went into a vicious cycle of crises, where the loss in output reduced public revenues and increased public borrowing through short-term treasury bills that were bought by domestic banks, which refinanced themselves through short-term loans from abroad-building up currency risks and setting the stage for the next crisis. Resulting high real interest rates reduced investment and prospects for long-term growth (see also Akyüz and Boratav, 2003). Whereas recovery from the first crisis in 1994 was relatively smooth, both in terms of GDP and employment, the second and especially the third crisis proved to be more severe. Their combined effect meant that per capita incomes were still at their 1997/98 levels in 2003 (see figure 18). Unemployment peaked briefly during 1999 and was back at its previous level of around 6.5 per cent in 2000-before the next crisis set in. The third crisis led to a dramatic rise in unemployment to 10.4 per cent in 2002 and has remained close to 10 per cent since. While employment had recovered largely in line with GDP during the first crises, unemployment has not fallen significantly after the last, most severe crisis—despite a strong rebound in GDP.

\section{The employment impact of the East Asian crisis}

That financial crises typically translate into crises of the real economy is also clearly evident from the experience of East Asia. In a survey of firms in Indonesia, Malaysia, Republic of Korea and Thailand, entrepreneurs list the drop in domestic demand, the rising costs for imported inputs and the high interest rates as the most important reasons for the drop in both output and capacity utilization during the 1997/98 crisis (see Dwor-Frécaut, Colaco and Hallward-Driemeier, 2000). The declining capacity utilization had adverse impacts on the average profitability and liquidity of firms, and many companies abandoned or scaled down planned investments (ibid.). Interest rate and currency shocks also forced many companies into bankruptcy as they found themselves unable to service their debt, much of which was denominated in foreign currency

15 Unfortunately, due to the expansion of geographical coverage from Greater Buenos Aires (until 1995) to 28 urban agglomerations (from 1996 onwards) the unemployment data are not directly comparable. 
Figure 18: Medium-term effects of the financial crises on unemployment in Turkey

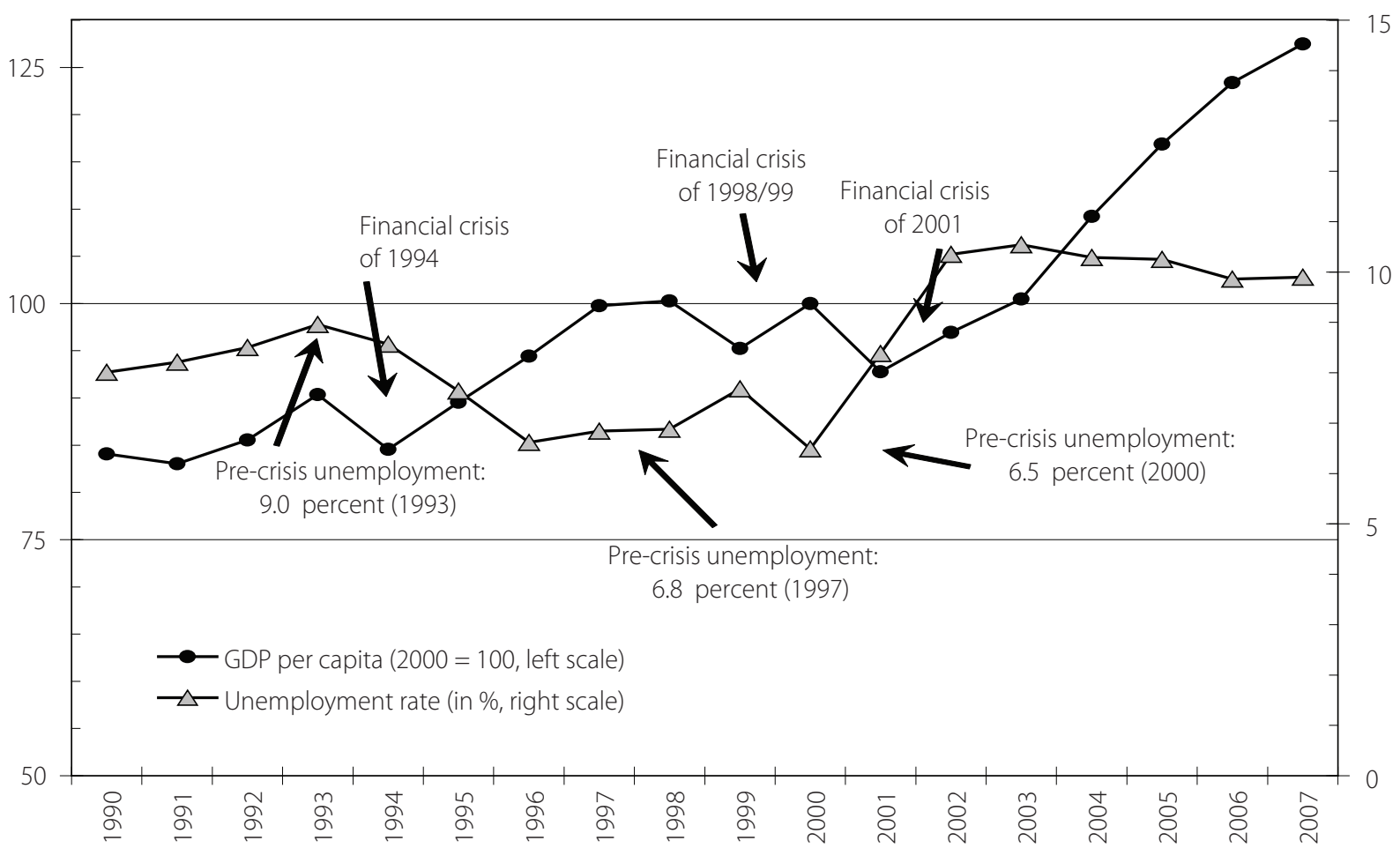

Source: World Bank, World Development Indicators, online database as of May 2009, series "GDP per capita (constant 2000 US dollars)"; ILO, Key Indicators of the Labour Market, 5th edition (2009).

(Kawai, Lieberman and Mako, 2000). Data from the countries most severely affected by the East Asian crisis show that many of the surviving firms reduced their workforce in 1998, while only a small fraction hired more staff (see Dwor-Frécaut, Colaco and Hallward-Driemeier, 2000). Unemployment increased throughout the region, and incomes fell, in some cases dramatically, pushing many people below the poverty line. According to ILO estimates, the number of working poor in South-East Asia (using the threshold of 1 US dollar per day) rose from its pre-crisis level of 33.7 million in 1996 to 50.6 million at the height of the financial crisis in 1998-an increase of almost 17 million (see Kapsos, 2004).

A more detailed look at the country level shows that in 1996, the year before the East Asian financial crisis, some countries had virtually achieved full employment, with unemployment rates of 1.1 per cent in Thailand, 2.0 per cent in the Republic of Korea and 2.5 per cent in Malaysia (figure 19). By 1998, the combination of production cutbacks and layoffs through bankruptcies had brought unemployment to 3.4 per cent in Thailand, or 1.1 million (up from 0.3 million). In addition, about 0.2 million workers left the labour force despite strong growth of the working age population. ${ }^{16}$ Many workers had to find a new source of income in the informal economy which had grown significantly during the crisis. This development is mirrored by a rise in the number of self-employed by 0.8 million. Hidden unemployment in the form of underemployment also increased almost twofold (from 2.3 million to 4.4 million). A further effect of the crisis was a decline in real wages by 4 per cent within one year (see Mahmood and Aryah, 2001). ${ }^{17}$

16 See ILO, Key Indicators of the Labour market, 5th edition (2009).

17 Women in urban areas suffered a disproportionate wage loss (-10.5 per cent), and workers in manufacturing ( -13 per cent) and constriction (-24 per cent) were also badly affected (Mahmood and Aryah, 2001). 
Figure 19: Medium-term effects of the East Asian financial crises on unemployment
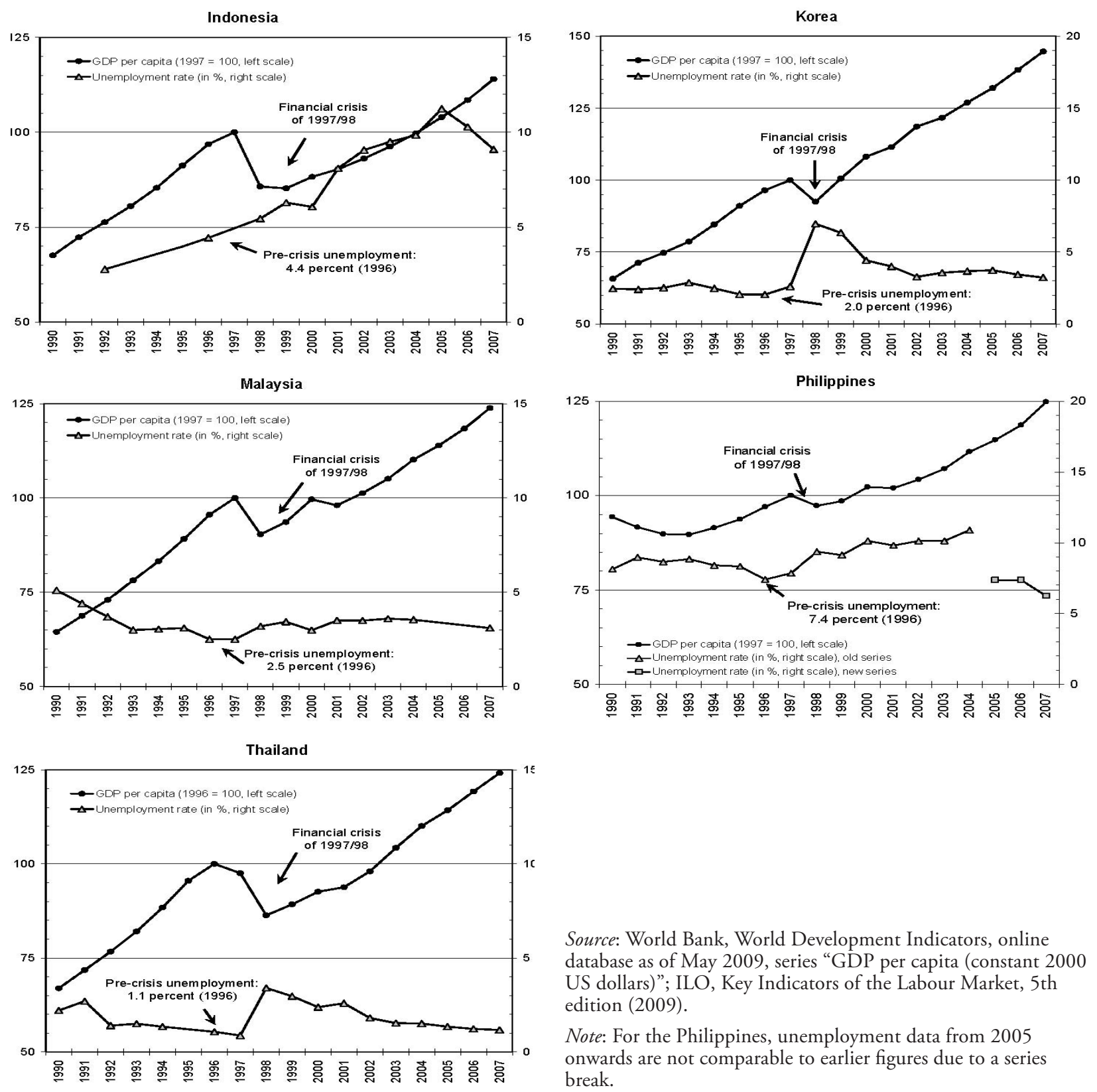

Source: World Bank, World Development Indicators, online database as of May 2009, series "GDP per capita (constant 2000 US dollars)"; ILO, Key Indicators of the Labour Market, 5th edition (2009).

Note: For the Philippines, unemployment data from 2005 onwards are not comparable to earlier figures due to a series break.

The labour market in the Republic of Korea suffered severely from the wave of redundancies that accompanied the bankruptcies of thirteen large conglomerates during 1997, and the reduction in the work force of the surviving companies. Delays in payments by the large corporations dragged many SMEs into the crisis; 8,200 of them failed in 1997 and a further 10,500 in 1998 (see Kawai, Lieberman and Mako, 2000). Open unemployment rose to 7.0 per cent or 1.5 million (up from 0.6 million), a level not seen in decades. Among the hardest-hit groups were manual production workers and those in clerical grades. By the first quarter of 1999, total employment had fallen to 19 million, down by 2.1 million from the fourth quarter of 1997 (see Kang and others, 2001). The disparity between the growth in unemployment and the far larger decline in employment can be attributed to the fact that around 350,000 workers (in particular women) left the labour force altogether, resulting in a decline of the labour force participation rate by almost 2 percentage points (ILO, 2009a). 
The increase in unemployment was less dramatic in Malaysia, where the rate rose by less than 1 percentage point. Nonetheless, around 250,000 formal sector jobs were lost in 1998 (see Jomo, 2001). Many of the retrenched workers were foreign migrant workers, which cushioned the effect on the domestic labour market (see Mansor and others, 2001) but dispersed some of the negative impact to other countries. ILO data also show that agricultural employment expanded by 135,000 in 1998. The absorption of labour by the primary sector helped to contain the rise in open unemployment, but contributed to falling labour productivity in agriculture (ILO, 2009a; World Bank, 2009a).

Indonesia, with 4.4 percent unemployment in 1996, and the Philippines, with 7.4 percent, went into the financial crisis with considerably higher unemployment. From that higher base, about 2.5 million workers lost their jobs in Indonesia in 1997/1998, among them 1 million in manufacturing alone (see Islam and others, 2001). The fall in industry and services employment was offset by an expansion of agriculture employment, so that open unemployment grew only modestly during 1998 despite strong labour force growth. However, unemployment continued to rise in subsequent years and reached 11.2 per cent in 2005 . Real earnings also fell by about 40 per cent during the crisis and were still about 10 per cent below their precrisis level in 2000 (Dhanani and Islam, 2004). In the Philippines, where the crisis had a comparatively mild economic impact, unemployment rose to 9.4 per cent in 1998 (+2 percentage points) and has, much like in Indonesia, continued on an upward path during the early 2000 s. $^{18}$

The East Asian experience shows that progress in returning to pre-crisis unemployment is generally far slower than the pace of economic recovery. Although all five countries returned to positive growth in 1999 or 2000, unemployment rates continued to increase in Indonesia, Malaysia, Philippines and the Republic of Korea and peaked only four or five years after the return to positive growth. This shows that the recovery of the labour market lagged far behind the economic recovery. Although all four countries have regained their pre-crisis GDP level — the Republic of Korea as early as 1999 and Indonesia in 2005-Thailand returned to pre-crisis levels of unemployment only in 2007, a decade after the East Asian Crisis. ${ }^{19}$ Thus, while countries have largely managed to recover from the economic impact of the crisis, the devastating labour market effect seems to be much more long-lived.

\section{Financial globalization and labour: main findings}

On balance, the capital account liberalization that many developing countries embarked upon in the 1990s has delivered disappointing results. ${ }^{20}$

The preceding discussion has shown that capital account liberalization not only fell far short of expectations, but did serious harm to some countries and had a disproportionately negative effect on labour. The following six main conclusions emerge:

18 Due to a series break in the data from the Philippines, unemployment rates from 2005 onwards are not directly comparable to the earlier series.

19 No conclusive assessment is possible for the Philippines, where a change in survey methodology led to a series break in 2005.

20 This disappointment is well summarized in a recent World Bank report that reviews the growth performance of the 1990s: "Contrary to expectations, financial liberalization did not add much to growth, and it appears to have augmented the number of crises. As expected, deposits and capital inflows rose sharply as a result of liberalization. But, other than in a few East Asian and South Asian countries, capital markets did not provide resources for new firms. Numbers of stock market listings declined, even in the newly created markets in the transition countries that were sometimes used for privatizations. Also, although relevant time-series data on access are weak, and contrary to expectations, it appears that access to financial services did not improve substantially after liberalization.” (World Bank, 2005b). 
1. In the absence of adequate institutions, capital account liberalization has little direct benefit for growth. This is especially true for poor countries where the institutional gap is the greatest, althought it is also true for middle-income countries where capital inflows were not used to fill unmet investment needs.

2. Even if capital account liberalization is managed prudently, there is a cost to developing countries. In order to cushion the effects of sudden outflows, developing countries have sterilized inflows and built up large reserves. Since these are mainly held in low-yield treasury bonds issued by industrialized countries, the opportunity cost is large.

3. Capital account liberalization has left developing countries vulnerable to crises. These are often not triggered by a deterioration of a country's fundamental economic status, but by forces in the international financial system. The output losses associated with such crises are large, and even a subsequent recovery is usually insufficient to set a country back on its old growth path.

4. The negative effects of financial crises on the labour market can be detected in a number of indicators. Open unemployment typically rises substantially during a crisis, real wages often fall, underemployment rises, and workers shift from the formal sector to agriculture and the informal economy.

5. Labour markets typically lag the economic recovery by several years. Even when GDP per capita has reached its pre-crisis level, the consequences of the crisis are normally still evident in higher unemployment compared to pre-crisis levels. This lag signifies that labour pays a disproportionate cost.

6. Tracking the evolution of the labour share in national income also shows that financial openness and financial crises diminish labour's share. Financial openness is associated with stronger bargaining power for capital vis-à-vis labour. Financial crises have a negative and persistent effect on the share of labour compensation in GDP.

\section{The effect of the current crisis on labour and possible policy responses}

The above analysis of the effects on labour in previous crises provides a useful indicator for an analysis of the current crisis, even though information regarding its impact on employment and labour is yet to be fully compiled.

The first important point to observe in this context is that the current recession and crisis affect developing countries more than previous crises did. The World Bank's recent Global Economic Prospects (2010) argues that the severity of this recession is far more than that of earlier recessions (figure 20). This assessment is at variance with earlier evaluations of the effects of the current recession on developing countries. For example, the IMF World Economic Outlook 2008 argued that greater delinking was taking place between industrialized and developing economies, and that developing countries would be less affected by a crisis which had started in the developed world. However the decline in trade volumes and values, the substantial shrinking of FDI, as well as a reversal in the fast-growing trend of increasing remittances, have had substantial consequences for developing countries and especially for the poorer segments of their population. (See United Nations, 2010; World Bank, 2010). 
Figure 20: A comparison of downturns in developing countries during several recent recessions

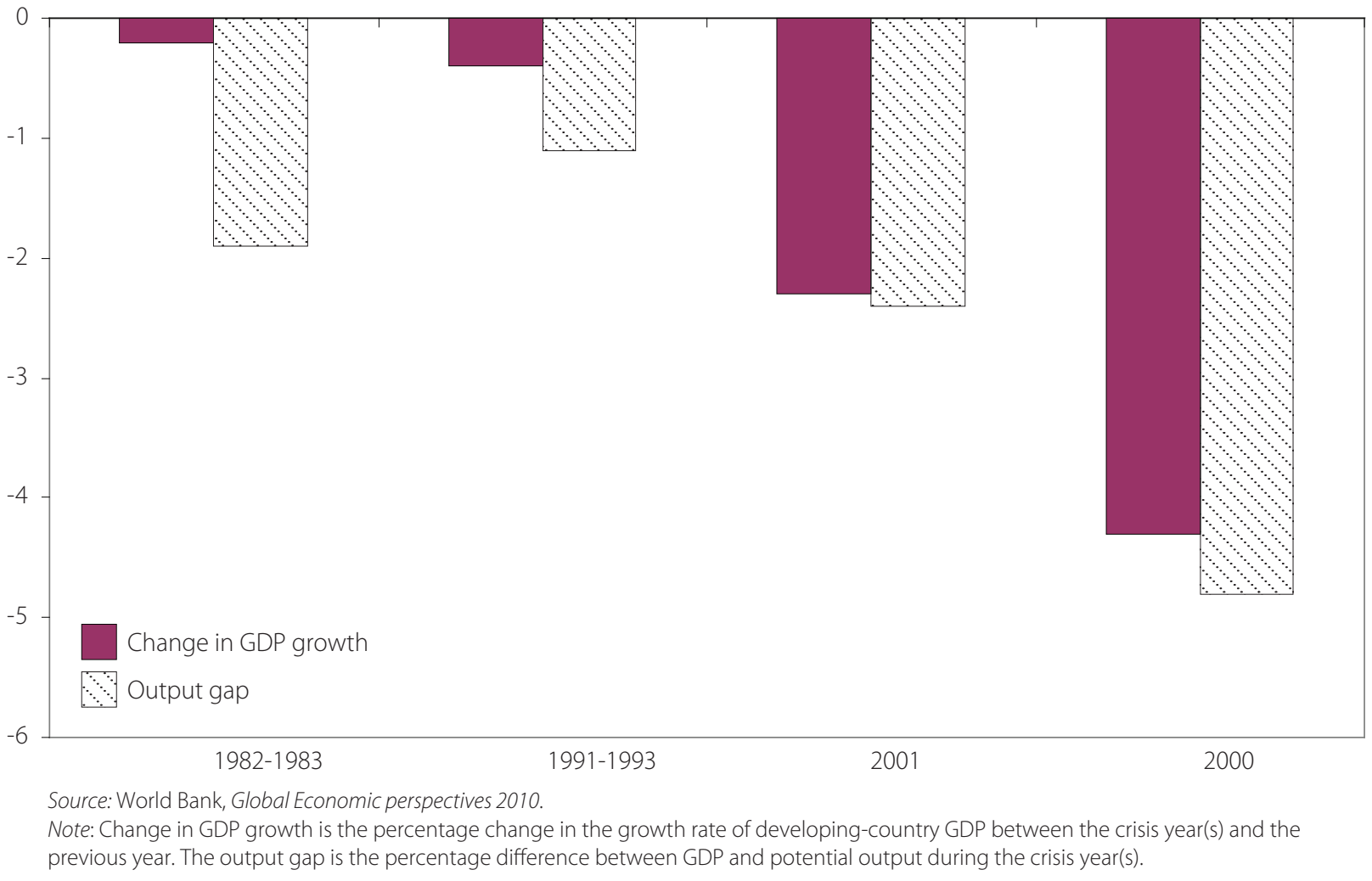

Many saw signs of "deglobalization" in the decline of trade, FDI and remittances. One could argue that such a deglobalization might be beneficial for developing countries, as it would reduce their exposure to the caprices of big players in the global financial and currency markets. Indeed, the current crisis has led to the larger developing countries having a somewhat greater influence in economic decision-making. This can be seen in the rise to prominence and the increasing importance of the Group of Twenty (G20), which is replacing the Group of Seven (G7). However, this is a far cry from the changes in global governance that Stiglitz (2009) argues as being necessary to avoid future crises.

Furthermore the decline in trade, FDI and remittances was not the consequence of any agreed change in international policies towards globalization. Instead, they are the outcome of the serious downturn in GDP in industrialized countries, alongside rising tendencies of protectionism and deterioration of attitudes towards foreign workers.

The position of labour in the current crisis is actually extremely worrying. The trends over the last two decades (reported above) indicate that the economic bubble generated by financial globalization in the second half of the first decade of the twenty first century did not favour most participants in the labour market, as low employment elasticities, growing inequality and persistent informalization of labour have attested to. Only a small minority has really been profiting from this process. Now that the bubble has burst, we notice the consequences to be highly asymmetric. As ILO Global Employment Trends 2010 documents, workers are suffering from consequences, and Ravaillion (2009) reports a substantial increase of the number of households in poverty as a consequence of the crisis. Also, the lag in employment recovery after a financial crisis, which we noticed earlier crises, is proving to be true for this crisis, too. Yet, the executives of financial institutions, whose behaviour led to the crisis, continue to get high bonuses and remuneration packages. 
In brief: the current spate of globalization has made labour more precarious, a trend that has been magnified by the current crisis. This picture is consistent with the policy reaction to the crisis in many countries, where Governments have (rightly) acted as a banker of last resort to avoid the collapse of the financial system. But, despite stimulus plans, monetary easing and some labour market policies, Governments have not really acted as an employer of last resort.

Thus, it seems important to frame policies favouring labour in the current context along the following two lines.

First, it is necessary to introduce and strengthen those national and international policies which try to undo the trends of precariousness and increasing inequality generated by (financial) globalization. Examples of such policies can be found in van der Hoeven and Luebker (2007), United Nations (2007) and World Commission on the Social Dimension of Globalisation (2004).

Second, in addition to the policies above, it is necessary to apply special policies to deal with the fallout of the current crisis. Examples of such policies include employment policy schemes (Wray, 2009), special labour market policies (Cazes and others, 2009) and cash transfers (Standing, 2007). The costs of these policies are often a fraction of the support the financial institutions and large industries have received recently. They can be financed initially as part of the current stimulus packages and, once the economy has picked up, from increased tax revenues or from reimbursements to the Governments by bailed out financial institutions.

It is important to base policy interventions simultaneously on policies dealing with the structural problems, which financial globalization has caused, and on policies aimed at assisting those who fall into poverty or experience poor working conditions as a consequence of the crisis. The current crisis is clearly the outcome of a long-term trend of financial globalization, which, if not arrested in its current form, may well lead to a new crisis. 


\section{References}

Adams, Richard H. Jr., and John Page (2005). Do international migration and remittances reduce poverty in developing countries? World Development, vol. 33, No. 10, pp. 1645-1669.

Aguiar, Mark A. (2005). Investment, devaluation, and foreign currency exposure: The case of Mexico. Journal of Development Economics, vol. 78, pp. 95-113.

Akyüz, Yilmaz (2006). Issues in macro-economic and financial policies, stability and growth. Policy Integration Department, Working paper No. 73. International Labour Office, Geneva.

Akyüz, Yilmaz, and Korkut Boratav (2003). The making of the Turkish financial crisis. World Development, vol. 31, No. 9, pp. 1549-1566.

Amsden, Alice, and Rolph van der Hoeven (1996). Manufacturing output, employment and real wages in the 1980s: Labour's loss until century's end. Journal of Development Studies, vol. 32, No. 4, pp. 506-530.

Angeles-Castro, G. (2006). The effects of economic liberalization on income distribution: A panel data analysis. In Wages, employment, distribution and growth, Hein, E. Heise, A. and Truger, A., eds. Basingstoke: Palgrave Macmillan.

Averbug, André (2002). The Brazilian economy in 1994-1999: From the real plan to inflation targets.

Carstens, Agustìn, and Moisés J. Schwartz (1998). Capital flows and the financial crisis in Mexico. Journal of Asian Economics, vol. 9, No. 2, pp. 207-226.

Cazes, S., Verick, S. and Heuer, C. (2009). Labour market policies in times of crisis, Employment Working Paper No. 35. ILO: Geneva.

Cerra, Valerie, and Sweata Chaman Saxena (2005). Growth dynamics: The myth of economic recovery. IMF working paper No. 05/147. International Monetary Fund, Washington, D. C.

Cerra, V., and Saxena, S. W. (2008). Growth Dynamics: The myth of economic recovery. American Economic Review, vol. 98, No. 1, pp. 419-457.

Cinquetti, Carlos A. (2000). The real plan: Stabilization and destabilization. World Development, vol. 28, No. 1, pp. $155-171$.

Damill, Marco, Roberto Frenkel, and Roxana Maurizio (2002). Argentina: A decade of currency board—An analysis of growth, employment and income distribution. ILO employment paper No. 2002/42. International Labour Office, Geneva.

Daseking, Christina, Atish R. Ghosh, Alun H. Thomas and Timothy D. Lane (2004). Lessons from the Crisis in Argentina. International Monetary Fund, Washington, DC.

de Gregorio, José, Sebastian Edwards, and Rodrigo O. Valdés (2000). Controls on capital inflows: Do they work? Journal of Development Economics, vol. 63, No. 1, pp. 59-83.

Demir, Firat (2004). A failure story: Politics and financial liberalization in Turkey, revisiting the revolving door hypothesis. World Development, vol. 32, No. 5, pp. 851-869.

Dhanani, Shafiq, and Iyanatul Islam (2004). Indonesian Wage Structure and Trends, 1976-2000. International Labour Office, Geneva.

Diwan, Ishac (2001). Debt as sweat: Labour, financial crisis, and the globalization of capital. World Bank, Washington, D. C. Mimeo. Draft as of July 2001.

Dwor-Frécaut, Dominique, Francis X. Colaco, and Mary Hallward-Driemeier, eds. (2000). Asian Corporate Recovery: Findings from Firm-level Surveys in Five Countries. World Bank, Washington, D. C.

Easterly, William, Roumeen Islam, and Joseph Stiglitz (2001). Shaken and stirred: Volatility and macroeconomic paradigms for rich and poor countries. In Annual Bank Conference on Development Economics 2000, Boris Preskovic and Nicholas Stern, eds. World Bank, Washington, D. C., pp. 191-212.

Edison, Hali, and Carmen M. Reinhart (2001). Stopping hot money. Journal of Development Economics, vol. 66, pp. $533-553$.

Edison, Hali J., Michael W. Klein, Luca Antonio Ricci, and Torsten Sløk (2004). Capital account liberalization and economic performance: Survey and synthesis, IMF Staff Papers, vol. 51, No. 2, pp. 220-256.

Freeman, R. B. (2004). Trade Wars: The Exaggerated Impact of Trade in Economic Debate. The World Economy, vol. 27, No. 1, pp. 1-23, 01.

Harrison, Anne (2002). Has globalization eroded labour's share? Some cross country evidence. National Bureau of Economic Research, Cambridge, Massachusetts. Mimeo.

Hutchison, Michael M., and Ilan Noy (2006). Sudden stops and the Mexican wave: Currency crises, capital flow reversals and output loss in emerging markets. Journal of Development Economics, vol. 79, No. 1, pp. 225-248. 
Ibarra, Carlos A. (1999). Disinflation and the December 1994 devaluation in Mexico. International Review of Applied Economics, vol. 13, No. 1, pp. 55-69.

ILO (2002). Investment in the global economy and decent work. Governing body paper GB 285/WPSDG /2. International Labour Office, Geneva.

IMF Independent Evaluation Office (2005). The IMF's Approach to Capital Account Liberalization. International Monetary Fund, Washington, D. C.

IMF (2008). World Economic Outlook 2008. Washington, D. C., April.

Islam, Rizwanul, Gopal Bhattacharya, Shafiq Dhanani, Max Iacono, Farhad Mehran, Swapna Mukhopadhyay, and Phan Thuy (2001). The economic crisis: Labor market challenges and policies in Indonesia. In East Asian Labor Markets and the Economic Crisis, Gordon Betcherman and Riswanul Islam, eds. World Bank and International Labour Office, Washington, D. C. and Geneva, pp. 43-96.

Jomo, Kwame S. (2001). Financial crisis and macroeconomic policy responses to the 1997-8 financial crisis in Malaysia. Paper prepared for the workshop on macroeconomic policies and employment, Bangkok, December.

Jomo, Kwame S. (2005). Malaysia’s September 1998 controls: Background, context, impacts, comparisons, implications, lessons. G-24 discussion paper series No. 36. United Nations: Geneva and New York.

Kaminsky, Graciela L., Carmen Reinhart and Carlos Végh (2004). When it rains, it pours: Procyclical capital flows and macro economic policies. NBER working paper No. 10780. National Bureau of Economic Research, Cambridge, Massachusetts.

Kang, Soon-Hie, Jaeho Keum, Dong-Heon Kim, and Donggyun Shin (2001). Korea: Labor market outcomes and policy responses after the crisis. In East Asian Labour Markets and the Economic Crisis, Gordon Betcherman and Rizwanul Islam, eds. World Bank and International Labour Office, Washington, D. C. and Geneva, pp. 97-139.

Kapsos, Steven (2004). Estimating growth requirements for reducing working poverty: Can the world halve working poverty by 2015? ILO Employment Strategy paper No. 2004/14. International Labour Office, Geneva.

Kawai, Masahiro, Ira Lieberman, and William P. Mako (2000). Financial stabilization and initial restructuring of East Asian corporations: Approaches, results, and lessons. In Managing Financial and Corporate Distress: Lessons from Asia, Charles Adams, Robert E. Litan, and Michael Pomerleano, eds. Brookings Institution Press, Washington, D. C., pp. 77-136.

Kose, M., Ayhan, Eswar Prasad and Marco Terrones (2003). Financial integration and macroeconomic volatility. IMF Staff Papers, vol. 50, pp. 119-142.

Kucera, D. and Roncolato, L. (2008). Informal Employment: Two contested policy issues, ILR, vol. 147, No. 4, pp. $321-348$.

Lee, Eddy (1998). The Asian Financial Crisis. The Challenge for Social Policy. International Labour Office, Geneva.

Lee, Kang-kook, and Arjun Jayadev (2005). Capital account liberalization, growth and the labor share of income: Reviewing and extending the cross-country evidence. In Capital Flight and Capital Controls in Developing Countries, Gerald Epstein, ed. Edward Elgar, Cheltenham, pp. 15-57.

Mahmood, Moazam, and Gosah Aryah (2001). The labour market and labour policy in a macroeconomic context: Growth, crisis, and competitiveness in Thailand. In East Asian Labour Markets and the Economic Crisis, Gordon Betcherman and Rizwanul Islam, eds. World Bank and International Labour Office, Washington, D. C. and Geneva, pp. 245-292.

Malloney, W. (2004). Informality Revisited. World development, vol 32, No. 7, pp. 1159-1178.

Mansor, Norma, Tan Eu Chye, Ali Boerhanoeddin, Fatimah Said and Saad Mohd Said (2001). Malaysia: Protecting workers and fostering growth. In East Asian Labor Markets and the Economic Crisis, Gordon Betcherman and Rizwanul Islam, eds. World Bank and International Labour Office, Washington, D. C. and Geneva, pp. 141-194.

Mishkin, Frederic S. (1999). Lessons from the tequila crisis. Journal of Banking \& Finance, vol 23, pp. 1521-1533.

Morandé, Felipe G., and Matías Tapia (2002). Exchange rate policy in Chile: From the band to floating and beyond. Central Bank of Chile working paper No. 152. Santiago de Chile.

Prasad, Eswar, Kenneth Rogoff, Wei Shang-Jin, and M. Ayhan Kose (2003). Effects of financial globalization on developing countries: Some empirical evidence. International Monetary Fund, Washington, D. C. Mimeo.

Prasad, Eswar, Kenneth Rogoff, Wei Shang-Jin, and M. Ayhan Kose (2004). Financial globalization, growth and volatility in developing countries. NBER working paper No. 10942. National Bureau of Economic Research, Cambridge, Massachusetts.

Rada ,C., and L. Taylor (2006). Developing and Transition Economies in the Late 20th Century: Diverging Growth Rates, Economic Structures, and Sources of Demand, DESA Working Paper No. 34, United Nations, New York.

Rani, U. (2008). The Impact of changing work patterns on inequality, Working paper No. 19308, IILS, Geneva. 
Ratha, Dilip (2005). Workers' remittances: An important and stable source of external development finance. In Remittances: Development Impact and Future Prospects, Samuel Munzele Maimbo and Dilip Ratha, eds. World Bank, Washington, D. C., pp. 19-51.

Ravaillon, M. (2009). The crisis and the world's poorest. In Growing out of crisis, World bank Institute, December, pp. 16-19.

Reinhart, Carmen and Kenneth Rogoff (2009). The Aftermath of Financial Crises. NBER Working Paper No. 14656. National Bureau of Economic Research, Cambridge, Massachusetts.

Rodrik, Dani (1998). Who needs capital-account convertibility? Princeton Essays in International Finance vol. 207, pp. 55-65.

Rodrik, Dani (2003). Growth strategies. NBER working paper No. 10050. National Bureau of Economic Research, Cambridge, Massachusetts.

Rodrik, Dani (2006). The social cost of foreign exchange reserves. NBER working paper No. 11952. National Bureau of Economic Research, Cambridge, Massachusetts.

Singh, A. (2003). Capital account liberalization, free long-term capital flows, financial crisis and development. Eastern Economic Journal, vol. 29, No. 2, pp. 191-216.

Solimano, Andrés, and Guillermo Larraín (2002). From economic miracle to sluggish performance: Employment, unemployment and growth in the Chilean economy. Paper prepared for the ILO multidisciplinary Team, Santiago de Chile. International Labour Office, Santiago de Chile.

Standing, G. (2007). How Cash Transfers Boost Work and Economic Security. DESA Working Paper No.58, United Nations, New York.

Stewart, F., G. Ranis and A. Ramirez (2002). Economic Growth and Human Development. In 2002, Readings in Human Development, Fukida Parr, S. and Kumar, A. K. S., eds., Oxford University Press, New Delhi.

Stiglitz, J. (2000). Capital market liberalization, economic growth, and instability. World Development, vol. 28, No. 6, pp. 1075-1086.

Stiglitz, J. (2009a). The global crisis, social protection and jobs. International Labour Review, vol. 148, No.1-2 pp. 1-13.

Stiglitz, J. (2009b). The imperative for improved global economic coordination. In Growing out of crisis, World Bank Institute,December 2009, pp. 39-42.

UNCTAD (2001). Trade and Development Report 2001. United Nations Conference on Trade and Development, Geneva.

UNCTAD (2003). Management of Capital Flows: Comparative Experiences and Implications for Africa. United Nations Conference on Trade and Development, Geneva.

United Nations (2005). Report on the World Social Situation 2005: The Inequality Predicament. New York.

United Nations (2007). Report on the World Social Situation 2007: The Employment Imperative. New York.

United Nations (2010). World Economic and Social Survey2010: Retooling Global Development. New York.

van der Hoeven, R., and M. Luebker (2007). Financial Openness and Employment: The Need for Coherent International and National Policies. In Towards full and decent employment, Ocampo, J. A. and Jomo, K. S., eds. London: Zed Books.

van der Hoeven, R., and L. Taylor (2000). Introduction: Structural Adjustment, Labour Markets and Employment: Some considerations for Sensible people. Journal of Development Studies, vol. 36, No. 4 (April).

van der Hoeven, Rolph, and Catherine Saget (2004). Labour market institutions and income inequality: What are the new insights after the Washington Consensus? In Inequality, Growth, and Poverty in an Era of Liberalization and Globalization, Giovanni Andrea Cornia, ed. WIDER Studies in Development Economics. Oxford University Press, Oxford, pp. 197-220.

World Bank (2005a). Global Economic Prospects 2006: Economic Implications of Remittances and Migration. Washington, D. C.

World Bank (2005b). Economic Growth in the 1990s. Learning from a Decade of Economic Reform. Washington, D. C.

World Bank (2010). Global Economic Prospects 2010. Washington, D. C.

Wray, R. L. (2009). The Social and Economic Importance of Full Employment. Working paper No. 560, The Levy Economics Institute of Bard College, Annandale-on-Hudson, New York.

WCSDG (2004). A Fair Globalization: Creating Opportunities for All. World Commission on the Social Dimension of Globalization, International Labour Office, Geneva. 


\section{Data Sources}

ILO (2009a). Key Indicators of the Labour Market. 5th edition. International Labour Office, Geneva.

ILO (2009b). ILO database Laborsta, EAPEP, Version 5. International Labour Office, Geneva.

IMF (2009). Balance of Payments Statistics Yearbook. International Monetary Fund, Washington, D. C.

UNCTAD (various years). World Investment Report. United Nations Conference on Trade and Development, Geneva.

UNCTAD (2009). Handbook of Statistics 2008. United Nations Conference on Trade and Development, Geneva. Online version.

World Bank (2009a). World Development Indicators 2008, online database. World Bank, Washington, D. C. CD-rom.

World Bank (2009b). Global Development Finance 2008, online database. World Bank, Washington, D. C. Online database. 